\title{
A MEZEI NYÚL (Lepus europaeus) ÁLLOMÁNYÁNAK VÁLTOZÁSA A DÉVAVÁNYAI TÚZOKVÉDELMI MINTATERÜLETEN ÉS KÉT KONTROLLTERÜLETEN (2008-2012)
}

\author{
Tirják László \\ Körös-Maros Nemzeti Park Igazgatóság \\ Körös-Maros National Park Directorate, \\ H-5540 Szarvas, Anna-liget 1., Hungary \\ e-mail: laszlo.tirjak@kmnp.hu
}

\begin{abstract}
TIRJÁK L.: CHANGES IN THE BROWN HARE (Lepus europaeus) POPULATION ON THE DÉVAVÁNYA GREAT BUSTARD CONSERVATION SITE AND ON TWO CONTROL SITES (2008-2012). Hungarian Small Game Bulletin 13: 83-123. http://dx.doi.org/10.17243/mavk.2017.083

The Körös-Maros National Park Directorate established the Dévaványa Great Bustard Conservation Site in 2003. The primary objective of the establishment was the implementation of some special Great Bustard conservation measures, such as the testing and carrying out of various repatriation methods, and the designing of a habitat management model. The Great Bustard Conservation Site is a 398 hectare enclosure surrounded by a special fence, where medium-sized or larger carnivores and omnivorous mammals that would have a significant impact on ground-nesting birds had been eliminated. The species excluded from the enclosure are Red Fox (Vulpes vulpes), Golden Jackal (Canis aureus) whose population is increasing, Feral Dog (Canis familiaris), European Badger (Meles meles), Raccoon Dog (Nyctereutes procyonoides) and Wild Boar (Sus scrofa), which has by now become resident.

The study of the Brown Hare (Lepus europaeus) population living on the Great Bustard Conservation Site soon got into focus as it seemed plausible that the elimination of its main predator, the Red Fox, would change the parameters of the isolated population as compared to the populations living outside the enclosure.

The comparative study of the Brown Hare population included 9 surveys between autumn 2008 and autumn 2012. 3 sample sites were identified that differed in the presence or absence of Brown Hare taking by hunters and the occurrence of Red Fox. Populations were estimated twice a year (spring and autumn) during night surveys using spotlights. The habitat choice of observed Brown Hares was also recorded.

Population density data were evaluated against weather conditions, habitat changes and actual vegetation parameters. The analysis of the effects of extreme weather events received particular emphasis. The identification of habitat preferences will provide indispensable information to habitat management.

The greatest population density on the Great Bustard Interior Sample Site was in October 2008, with 3.76 specimens/ha. During the study period, three extreme weather events occurred that seriously impacted on the Brown Hare population (flooding and excessive rainfall, long-lasting snow cover, late summer drought). The floods and heavy rains in 2010 caused significant decline in all 3 populations. The long-lasting snow cover in February 2012 and the late summer - early autumn extreme drought resulted in mass die-offs within the Great Bustard Conservation Site, while the populations whose movements were not restricted fared successfully through the critical period. Due to these events, the population density on the Great Bustard Interior Sample Site decreased to 0.99 specimens/ha by the end of the study period.
\end{abstract}

KULCSSZAVAK: mezei nyúl, Túzokvédelmi Mintaterület, ragadozó kizárás, vörös róka KEY WORDS: Brown Hare, Great Bustard Conservation Site, predator removal, Red Fox 


\section{BEVEZETÉS}

A Körös-Maros Nemzeti Park Igazgatóság 2003-ban helyezte üzembe a dévaványai Túzokvédelmi Mintaterületet, amely azóta folyamatosan müködik. A kialakítás elsődleges céljaként egyes speciális túzokvédelmi feladatok ellátását, mint például a különböző típusú repatriációs módszerek kipróbálását, megvalósítását, illetve területkezelési modell kidolgozását jelölték meg a szakemberek.

A Túzokvédelmi Mintaterület bekaparás és beugrásgátlóval biztosított kerítéssel lezárt mintegy 398 hektáros terület, ahonnan a földön fészkelő madarakra jelentős hatással bíró, közepes méretü vagy annál nagyobb ragadozó, illetve vegyes táplálkozású emlősök kizárásra kerültek. Ebbe a körbe tartozik a környéken elöforduló vörös róka (Vulpes vulpes), a növekvő állományú aranysakál (Canis aureus), a kóbor kutya (C. familiaris), az európai borz (Meles meles), a nyestkutya (Nyctereutes procyonoides) és az egyre szaporodó és mára állandó vadfajjá váló vaddisznó (Sus scrofa).

A ragadozó emlősök kizárása azonban nemcsak a túzokokra, hanem az egész életközösségre, így a madarakra és az emlösökre is hatást gyakorol, illetve gyakorolhat. Ennek a kérdéskörnek a vizsgálata számos fontos tanulsággal szolgálhat, amely amellett hogy megalapozhatja a Mintaterület szakszerü üzemeltetését, a külső védett területek természetvédelmi kezelési feladatait is segítheti.

A Túzokvédelmi Mintaterületen élő mezei nyúl (Lepus europaeus) állományának vizsgálata hamar az érdeklődés középpontjába került, hiszen a számára veszélyt jelentő vörös rókától mentes a terület, ezért feltételezhető volt, hogy az izolált populációnak a jellemzői eltérnek a külső, szabadterületen élő állományok jellemzőitől. A vizsgálatok soronkívüli megindítását az is indukálta, hogy a mezei nyúl fontos zsákmányállata a térségben rendszeresen előforduló nagytestű ragadozó madaraknak, a rétisasnak (Haliaeetus albicilla), a parlagi sasnak (Aquila heliaca) és a szirti sasnak (A. chrysaetos). A Mintaterületen megnövekedő mezeinyúl-állomány pedig a sasok koncentrálódását eredményezheti, amely kedvezőtlenül hathat a benn tartózkodó vad vagy éppen repatriáció alatt álló túzokokra. Azonban a kérdés tisztázására csak a belső és a külső területek állományadatainak ismerete nyújthat lehetöséget.

Nemcsak a fenti szakmai probléma kezelése, hanem a mezei nyúlhoz kapcsolódó egyéb ismeretek megszerzése érdekében indult 2008 őszén a kutatási program. Ennek keretében 3 mintaterület került kijelölésre, ahol az elsőnél nincs vadászati hasznosítás és nincs jelen a vörös róka (Túzokvédelmi belső mintaterület), a másodiknál nincs vadászati hasznosítás, de a vörös róka előfordul (Réhely mintaterület), a harmadik mintaterület esetében a térségre jellemző vadászati hasznosítás folyik és a vörös róka is jelen van (Szilasok mintaterület). A mintaterületeken tavasszal és ősszel végeztük el az állományfelméréseket, ahol éjszakai reflektoros becslési módszert alkalmaztunk. A számlálások alkalmával rögzítésre került a mezei nyulak élőhelytípusonkénti előfordulása és a ragadozók jelenlétére vonatkozó adatok is.

A vizsgálat során összevetettem a három mintaterület mezeinyúl-állományának változásait 2008 ősze és 2012 ősze között, 9 felmérési időszak felhasználásával. A kapott adatok kiértékelése az időjárási körülmények, az élőhelyváltozások és az aktuális vegetációs jellemzők összehasonlításával történt. A munka során külön hangsúlyt fektettem a szélsőséges időjárási elemek hatásainak elemzésére. Az élőhelypreferencia meghatározása a későbbi élőhelyfejlesztések számára is megfelelő alapot tud nyújtani. 


\section{ANYAG ÉS MÓDSZER}

\subsection{A VIZSGÁLT TERÜLET KÖRNYEZETI VISZONYAI}

\subsubsection{Makroklimatikus viszonyok}

A Túzokvédelmi Mintaterület (1. ábra), illetve a kijelölt mintaterületek a Dévaványaisík földrajzi kistáj központi részén helyezkednek el, ahol az éghajlat száraz, mérsékelten meleg. Az éves napsütéses órák száma általában 1980 és 2000 óra közé esik, a földrajzi kistáj évi középhőmérséklete 10,3-10,4 ${ }^{\circ} \mathrm{C}$ körül alakul. Az éves lehullott csapadék mennyisége általában 510 és 540 mm. Az É-i, az ÉK-i és a D-i szél a leggyakoribb (DöVÉNYI, 2010).

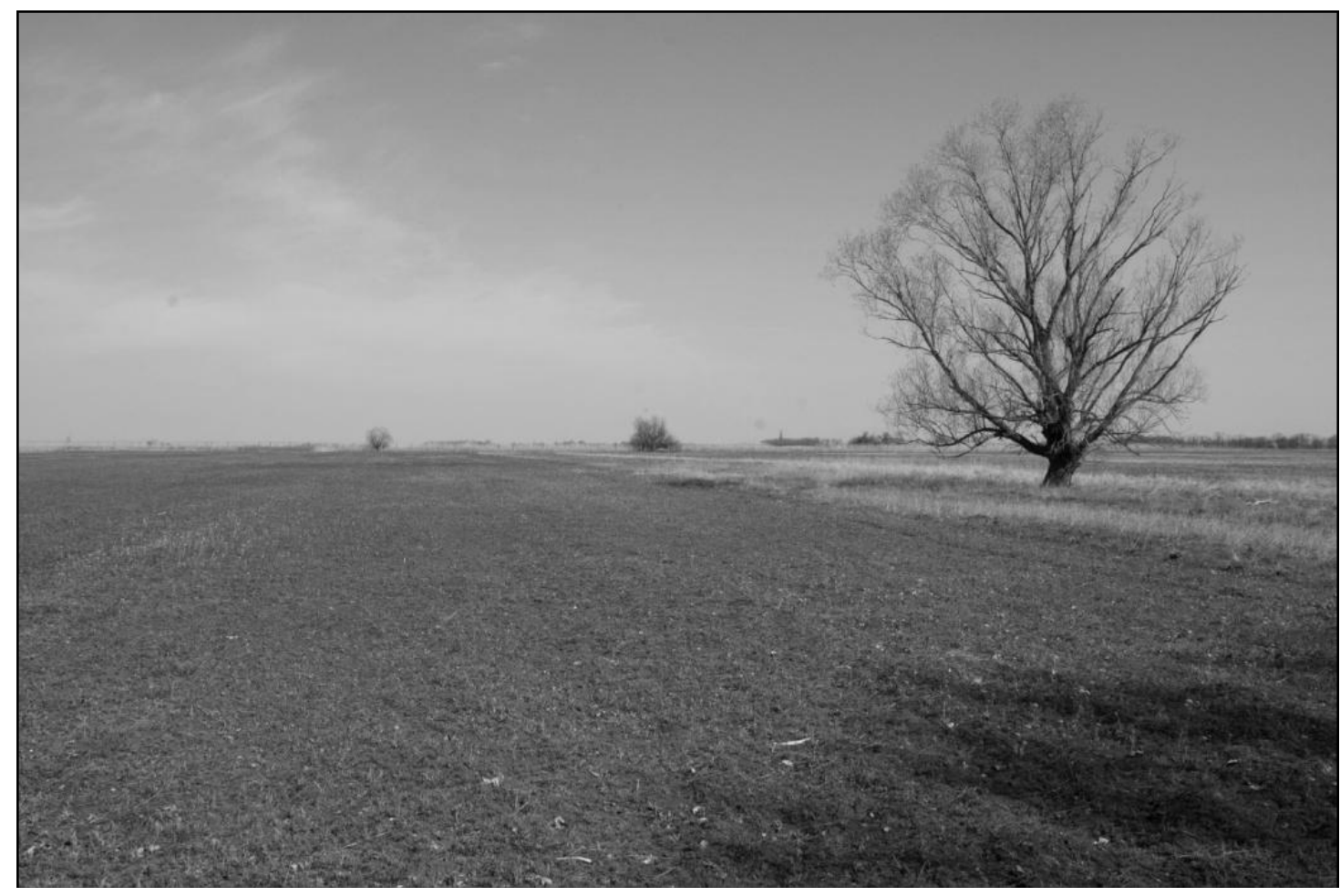

1. ábra: A Túzokvédelmi Mintaterület (Fotó: TIRJÁK L.)

Figure 1: The Great Bustard Conservation Site (Photo: L. TIRJAK)

A vizsgált 5 éves időszakra vonatkozóan a térség klimatikus viszonyainak bemutatásához 2 észlelő hely adatait dolgoztam fel. A csapadék esetében, ahol a lokalitásnak kiemelt jelentősége van, közvetlenül a terület szomszédságában található Túzokvédelmi Állomáson mért adatokat használtam fel. A méröhelyet a Körös-Maros Nemzeti Park Igazgatóság munkatársai üzemeltetik. A többi megadott érték az Országos Meteorológiai Szolgálat Békéscsabai Állomásának az adata. Az utóbbi észlelési hely Dévaványától délre, mintegy 40 kilométerre fekszik.

\section{Napfénytartam}

Az éves napfénytartam összege az elmúlt évtizedeknél magasabb értéket mutat. A vizsgált időszakban 2065 és 2643 óra között változott, legmagasabb értékét 2012-ben érte el (1. táblázat). 
1. táblázat: A napfénytartam (óra) alakulása 2008 és 2012 között (Békéscsaba) Table 1: Sunshine duration between 2008 and 2012 (Békéscsaba)

\begin{tabular}{cccccccccccccc}
\hline Év/ & Jan./ & Feb./ & Már./ & Ápr./ & Máj./ & Jún./ Júl./ & Aug./ & Sze./ & Okt./ & Nov./ & Dec./ & Összeg/ \\
Year & Jan. & Feb. & Mar. & Apr. & May. & June & July & Aug. & Sept. & Oct. & Nov. & Dec. & Sum \\
\hline $\mathbf{2 0 0 8}$ & 81 & 120 & 136 & 191 & 306 & 297 & 325 & 351 & 162 & 160 & 133 & 52 & 2314 \\
$\mathbf{2 0 0 9}$ & 49 & 84 & 132 & 311 & 313 & 287 & 373 & 310 & 261 & 127 & 89 & 44 & 2379 \\
$\mathbf{2 0 1 0}$ & 56 & 52 & 164 & 208 & 194 & 252 & 308 & 310 & 177 & 184 & 122 & 38 & 2065 \\
$\mathbf{2 0 1 1}$ & 45 & 84 & 178 & 272 & 311 & 307 & 263 & 359 & 298 & 211 & 136 & 42 & 2506 \\
$\mathbf{2 0 1 2}$ & 105 & 102 & 253 & 226 & 285 & 349 & 359 & 370 & 234 & 197 & 112 & 51 & 2643 \\
\hline $\begin{array}{c}\text { Átlag/ } \\
\text { Average }\end{array}$ & $\mathbf{6 7}$ & $\mathbf{8 8}$ & $\mathbf{1 7 2}$ & $\mathbf{2 4 2}$ & $\mathbf{2 8 2}$ & $\mathbf{2 9 8}$ & $\mathbf{3 2 6}$ & $\mathbf{3 4 0}$ & $\mathbf{2 2 7}$ & $\mathbf{1 7 6}$ & $\mathbf{1 1 8}$ & $\mathbf{4 6}$ & $\mathbf{2 3 8 1}$ \\
\hline $\begin{array}{l}\text { Minimum/ } \\
\text { Minimum }\end{array}$ & 45 & 52 & 132 & 191 & 194 & 252 & 263 & 310 & 162 & 127 & 89 & 38 & \\
\hline $\begin{array}{l}\text { Maximum// } \\
\text { Maximum }\end{array}$ & $\mathbf{1 0 5}$ & 120 & 253 & 311 & 313 & 349 & 373 & 370 & 298 & 211 & 136 & 52 & \\
\hline
\end{tabular}

A havi napfénytartam összegét megvizsgálva megállapítható, hogy minimumát decemberben éri el, átlagosan 46 órával (2. ábra). Augusztusig folyamatos a növekedés, ahol a havi átlagos érték 340 órát tesz ki. Ezt követően egyenletes csökkenés figyelhető meg a decemberi minimumig.

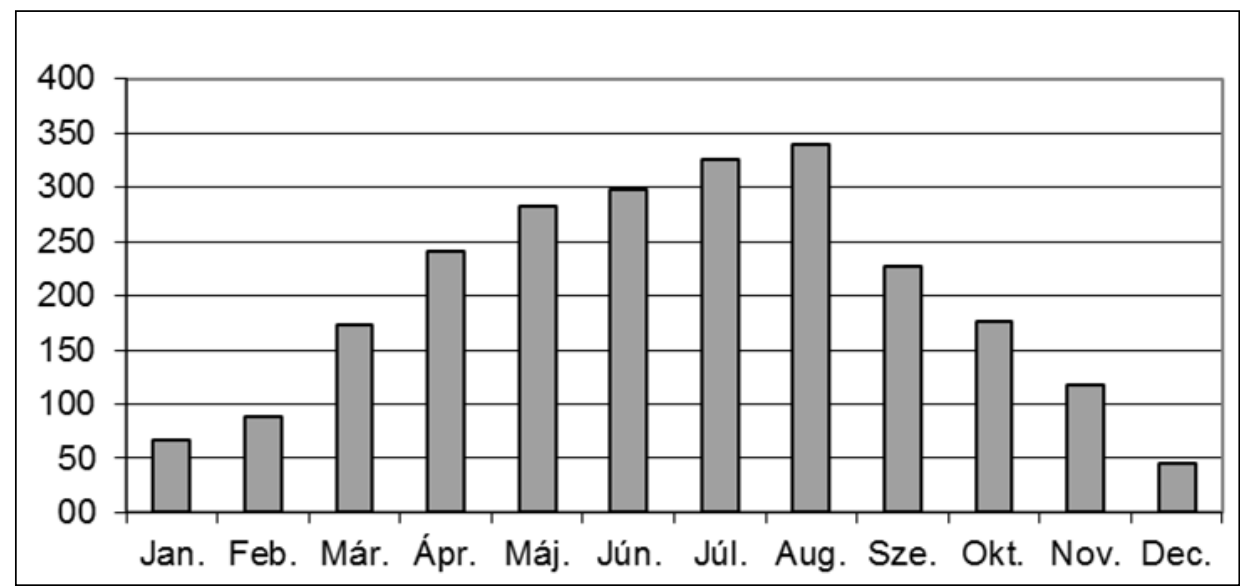

2. ábra: A napfénytartam havi megoszlása (óra) 2008 és 2012 között (Békéscsaba)

Figure 2: Monthly distribution of sunshine duration between 2008 and 2012 (Békéscsaba)

\section{Hömérséklet}

Az évi középhőmérséklet átlaga a vizsgált 5 éves időszakban (2. táblázat), a Békéscsabai Állomáson $11,5^{\circ} \mathrm{C}$ tett ki. Az éves minimum $11,0{ }^{\circ} \mathrm{C}(2011)$, az éves maximum pedig $12,2^{\circ} \mathrm{C}$ körül alakult (2009).

\section{Csapadék}

Az éves csapadék mennyiség 5 éves átlagban $485 \mathrm{~mm}$ értéket adott a Túzokvédelmi Állomás mérőhelyén. Az évek között azonban jelentős ingadozás figyelhető meg, míg a 2 nagyon száraz év $(2011,2012)$ esetében az éves csapadékmennyiség 350 mm körül alakult, 
addig 2010-ben ennek kétszeresét észlelték, meghaladva a $700 \mathrm{~mm}$-es értéket (3. táblázat). Ezekben az időszakokban a lehullott csapadék jelentősen belvízelöntéseket okozott, amely az élőhelyek részleges átalakulásához vezetett.

2. táblázat: A középhőmérséklet $\left({ }^{\circ} \mathrm{C}\right)$ alakulása 2008 és 2012 között (Békéscsaba)

Table 2: Change of mean temperature between 2008 and 2012 (Békéscsaba)

\begin{tabular}{|c|c|c|c|c|c|c|c|c|c|c|c|c|c|}
\hline $\begin{array}{l}\text { Ev/ } \\
\text { Year }\end{array}$ & $\begin{array}{l}\text { Jan./ } \\
\text { Jan. }\end{array}$ & $\begin{array}{l}\text { Feb./ } \\
\text { Feb. }\end{array}$ & $\begin{array}{l}\text { Már./ } \\
\text { Mar. }\end{array}$ & $\begin{array}{l}\text { Ápr./ } \\
\text { Apr. }\end{array}$ & $\begin{array}{l}\text { Máj./ } \\
\text { May. }\end{array}$ & $\begin{array}{l}\text { Jún./ } \\
\text { June }\end{array}$ & $\begin{array}{l}\text { Júl.// } \\
\text { July }\end{array}$ & $\begin{array}{l}\text { Aug./ } \\
\text { Aug. }\end{array}$ & $\begin{array}{l}\text { Sze./ } \\
\text { Sept. }\end{array}$ & $\begin{array}{l}\text { Okt./ } \\
\text { Oct. }\end{array}$ & $\begin{array}{l}\text { Nov./ } \\
\text { Nov. }\end{array}$ & $\begin{array}{l}\text { Dec./ } \\
\text { Dec. }\end{array}$ & $\begin{array}{l}\text { Összeg/ } \\
\text { Sum }\end{array}$ \\
\hline 2008 & 1,3 & 4,0 & 7,4 & 11,9 & 17,1 & 21,3 & 21,5 & 22,1 & 15,4 & 12,2 & 6,8 & 3,0 & 12,0 \\
\hline 2009 & $-1,1$ & 1,1 & 6,2 & 14,6 & 17,8 & 20,2 & 23,2 & 22,7 & 19,0 & 11,5 & 8,0 & 3,0 & 12,2 \\
\hline 2010 & $-1,0$ & 2,3 & 6,9 & 11,9 & 16,4 & 19,8 & 22,9 & 21,7 & 15,4 & 8,2 & 8,6 & $-0,1$ & 11,1 \\
\hline 2011 & $-0,7$ & $-1,1$ & 6,0 & 12,5 & 16,4 & 20,8 & 21,5 & 22,5 & 19,6 & 9,9 & 1,7 & 2,9 & 11,0 \\
\hline 2012 & 0,4 & $-6,0$ & 6,8 & 12,2 & 16,6 & 21,8 & 24,1 & 23,2 & 19,4 & 11,7 & 7,4 & $-0,5$ & 11,4 \\
\hline $\begin{array}{l}\text { Átlag/ } \\
\text { Average }\end{array}$ & $-0,2$ & 0,1 & 6,7 & 12,6 & 16,9 & 20,8 & 22,6 & 22,4 & 17,8 & 10,7 & 6,5 & 1,7 & 11,5 \\
\hline $\begin{array}{l}\text { Minimum/ } \\
\text { Minimum }\end{array}$ & $-1,1$ & $-6,0$ & 6,0 & 11,9 & 16,4 & 19,8 & 21,5 & 21,7 & 15,4 & 8,2 & 1,7 & $-0,5$ & \\
\hline $\begin{array}{l}\text { Maximum/ } \\
\text { Maximum }\end{array}$ & 1,3 & 4,0 & 7,4 & 14,6 & 17,8 & 21,8 & 24,1 & 23,2 & 19,6 & 12,2 & 8,6 & 3,0 & \\
\hline
\end{tabular}

3. táblázat: A csapadékösszeg (mm) alakulása 2008 és 2012 között (Dévaványa) Table 3: Change of precipitation between 2008 and 2012 (Dévaványa)

\begin{tabular}{cccccccccccccc}
\hline $\mathbf{E} \mathbf{v} /$ & Jan./ & Feb./ & Már./ & Ápr./ & Máj./ & Jún./ & Júl./ & Aug./ & Sze./ & Okt./ & Nov./ & Dec./ & Összeg/ \\
Year & Jan. & Feb. & Mar. & Apr. & May. & June & July & Aug. & Sept. & Oct. & Nov. & Dec. & Sum \\
\hline $\mathbf{2 0 0 8}$ & 18 & 14 & 53 & 43 & 51 & 125 & 55 & 28 & 29 & 29 & 23 & 34 & 503 \\
$\mathbf{2 0 0 9}$ & 27 & 18 & 47 & 40 & 8 & 110 & 41 & 5 & 9 & 7 & 122 & 34 & 469 \\
$\mathbf{2 0 1 0}$ & 21 & 51 & 8 & 80 & 87 & 105 & 60 & 97 & 66 & 15 & 88 & 90 & 769 \\
$\mathbf{2 0 1 1}$ & 20 & 17 & 20 & 8 & 53 & 24 & 112 & 13 & 12 & 12 & 0 & 38 & 328 \\
$\mathbf{2 0 1 2}$ & 24 & 4 & 4 & 23 & 40 & 33 & 115 & 3 & 26 & 36 & 16 & 34 & 358 \\
\hline $\begin{array}{c}\text { Átlag/ } \\
\text { Average }\end{array}$ & $\mathbf{2 2}$ & $\mathbf{2 1}$ & $\mathbf{2 6}$ & $\mathbf{3 9}$ & $\mathbf{4 8}$ & $\mathbf{7 9}$ & $\mathbf{7 7}$ & $\mathbf{2 9}$ & $\mathbf{2 8}$ & $\mathbf{2 0}$ & $\mathbf{5 0}$ & $\mathbf{4 6}$ & $\mathbf{4 8 5}$ \\
\hline $\begin{array}{l}\text { Minimum/ } \\
\text { Minimum }\end{array}$ & 18 & 4 & 4 & 8 & 8 & 33 & 41 & 3 & 9 & 7 & 0 & 34 & \\
\hline $\begin{array}{l}\text { Maximum// } \\
\text { Maximum }\end{array}$ & 27 & 51 & 53 & 80 & 87 & 125 & 115 & 97 & 66 & 36 & 122 & \multirow{2}{*}{90} & \\
\hline
\end{tabular}

Az éves csapadékösszeg a vizsgált időszakban erős ingadozást mutatott Dévaványa környékén (3. ábra).

Ha a vizsgált 5 éves időszak évenkénti csapadékösszegét összevetjük a 5 év átlagával, jól követhető az eltérés alakulása (4. ábra). Ennek az értéknek az ingadozása azt szemlélteti, hogy az egyes évek között mekkora különbségek mutatkoznak a térség vízháztartásában.

A Túzokvédelmi Mintaterület esetében, mivel részben zárt rendszer, különleges jelentőséggel bírnak és célszerü külön vizsgálni a szélsőséges időjárási körülmények hatásait.

A nyári hőmérsékleti adatok esetében a 2012-es esztendőt érdemes kiemelni. A hőség napok (56) és a forró napok (17) száma kimagasló értéket mutattak (4. táblázat). 


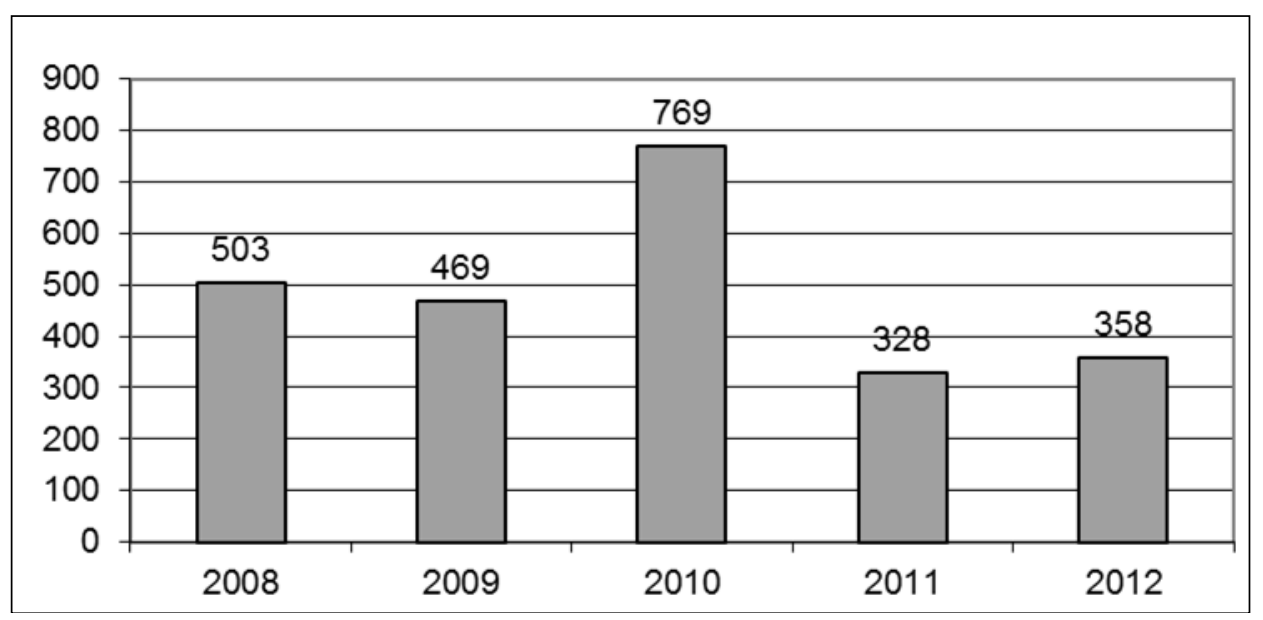

3. ábra: A csapadékösszeg éves alakulása ( $\mathrm{mm}) 2008$ és 2012 között (Dévaványa) Figure 3: Annual precipitation between 2008 and 2012 (Dévaványa)

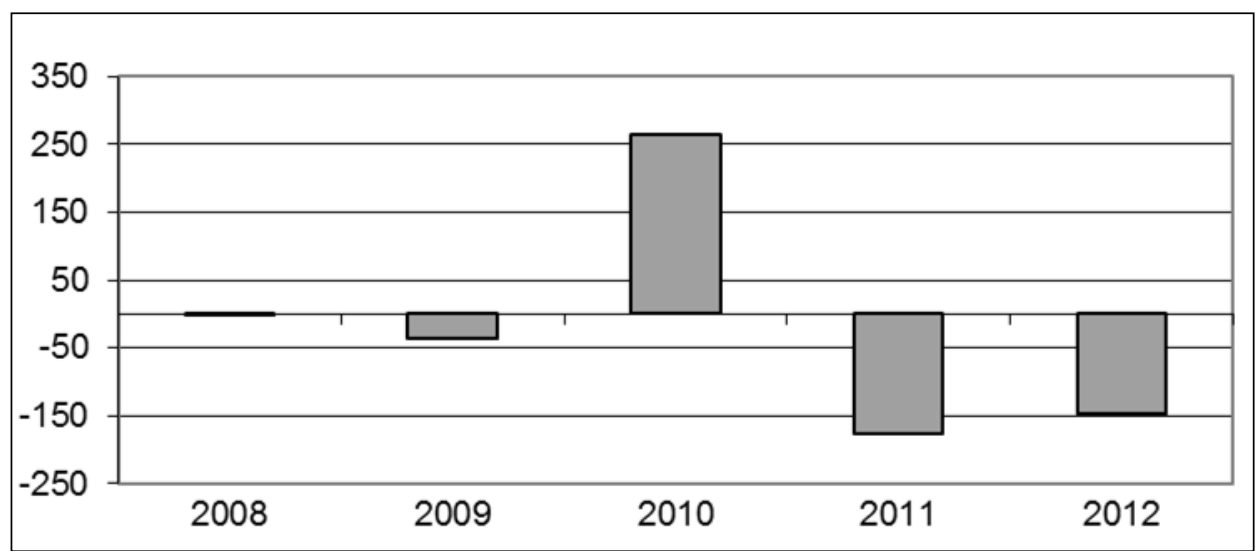

4. ábra: Az éves csapadékösszeg ( $\mathrm{mm}$ ) eltérése a 5 éves átlaghoz képest (Dévaványa) Figure 4: Deviation of annual precipitation from the five-year average (Dévaványa)

4. táblázat: A hőmérséklet szélső értékei a nyári félévben 2008 és 2012 között (Bcsaba) Table 4: Temperature extremes in the summer half year between 2008 and 2012 (Békéscsaba)

\begin{tabular}{|c|c|c|c|}
\hline \multirow{2}{*}{$\begin{array}{l}\text { Év/ } \\
\text { Year }\end{array}$} & $\begin{array}{c}\text { Nyári napok száma } \\
\text { Days with summerly weather }\end{array}$ & $\begin{array}{c}\text { Hőség napok száma } \\
\text { Hot days }\end{array}$ & $\begin{array}{c}\text { Forró napok száma } \\
\text { Heat days }\end{array}$ \\
\hline & $\max ->25^{\circ} \mathrm{C}$ & $\max ->30^{\circ} \mathrm{C}$ & $\max ->35^{\circ} \mathrm{C}$ \\
\hline 2008 & 98 & 36 & 0 \\
\hline 2009 & 120 & 39 & 0 \\
\hline 2010 & 79 & 34 & 0 \\
\hline 2011 & 106 & 45 & 0 \\
\hline 2012 & 120 & 56 & 17 \\
\hline $\begin{array}{l}\text { Átlag/ } \\
\text { Average }\end{array}$ & 105 & 42 & 3 \\
\hline $\begin{array}{l}\text { Minimum/ } \\
\text { Minimum }\end{array}$ & 98 & 34 & 0 \\
\hline $\begin{array}{l}\text { Maximum/ } \\
\text { Maximum }\end{array}$ & 120 & 56 & 17 \\
\hline
\end{tabular}


A téli időszak mindig külön megpróbáltatást jelent a mezei nyulak számára (5. táblázat). A téli időjárási körülmények, a tartós hófedettséggel párosuló fagyos ciklusok a táplálkozási lehetőségeket is alapvetően befolyásolhatják.

5. táblázat: A hőmérséklet szélső értékei a téli félévben 2007 és 2012 között (Békéscsaba)

Table 5: Temperature extremes in the winter half year between 2007 and 2012 (Békéscsaba)

\begin{tabular}{cccc}
\hline \multirow{2}{*}{$\begin{array}{c}\text { Év/ } \\
\text { Year }\end{array}$} & $\begin{array}{c}\text { Fagyos napok száma } \\
\text { Frosty days }\end{array}$ & $\begin{array}{c}\text { Téli napok száma } \\
\text { Days with winterly weather }\end{array}$ & $\begin{array}{c}\text { Zord napok száma } \\
\text { Days with rough weather }\end{array}$ \\
\cline { 2 - 4 }$\left(\min <-0^{\circ} \mathrm{C}\right)$ & $\left(\max <-0^{\circ} \mathrm{C}\right)$ & $\left(\min <-10^{\circ} \mathrm{C}\right)$ \\
\hline $\mathbf{2 0 0 7 / 2 0 0 8}$ & 82 & 22 & 3 \\
$\mathbf{2 0 0 8 / 2 0 0 9}$ & 82 & 25 & 10 \\
$\mathbf{2 0 0 9 / 2 0 1 0}$ & 72 & 24 & 14 \\
$\mathbf{2 0 1 0 / 2 0 1 1}$ & 93 & 32 & 19 \\
$\mathbf{2 0 1 1 / 2 0 1 2}$ & 124 & 30 & 11 \\
\hline $\begin{array}{c}\text { Átlag/ } \\
\text { Average }\end{array}$ & 91 & 27 & 3 \\
\hline Minimum/ & 72 & 22 & 19 \\
Minimum & 124 & 32 & 19 \\
\hline Maximum/ & & & \\
Maximum & & &
\end{tabular}

\subsubsection{A felmérések időszakának környezeti jellemzői}

\section{2008 ösz - (2008. október 1.,2.,6.)}

A 2008-as esztendő, a viszonylag alacsony csapadék mennyiség ellenére, a csapadékos évek sorába tartozik, ahol a vegetációs időszakban kifejezetten sok csapadék hullott. Az éves középhömérséklet $+1,8-+2,0{ }^{\circ} \mathrm{C}$-al magasabb értéket mutatott a sokévi átlagnál és a tenyészidőszak is $1,1{ }^{\circ} \mathrm{C}$-al volt melegebb az átlagos értéknél, a napfénytartam pedig 300 órával múlta felül a várt éves óraszámot.

A felmérések időszakában felhős vagy erősen felhős volt az égbolt, csapadék nem esett. A gyenge szellő, illetve szélcsend mellett nagyon meleg esték, éjszakák voltak a jellemzőek, a léghőmérséklet $+11,0{ }^{\circ} \mathrm{C}$ és $+19,5^{\circ} \mathrm{C}$ közé esett (6. táblázat).

A szántókon már itt-ott kikelt az őszi búza és az őszi káposztarepce, de növekedésük még gyenge volt, az észleléseknél a beláthatóságot nem befolyásolta. A Réhely mintaterületnél az első felmérési napot követően aratták le a napraforgót.

Rendkívüli időjárási helyzet: nem volt.

\section{2009 tavasz - (2009. március 31., április 1., 2.)}

Az előző, csapadékban gazdag esztendőt kifejezetten száraz tavasz követte. A tavaszi időszak középhőmérséklete $+2,2{ }^{\circ} \mathrm{C}$-al volt magasabb a sokéves átlagnál. Március második felében Dévaványa térségében egy átvonuló frontnak köszönhetően, jelentős mennyiségü eső esett, ezért a felmérést csúsztatni kellett, de végül a később érkező meleg hullám előtt sikerült eredményesen elvégezni.

A felmérések alkalmával az időjárást csapadékmentesség és szélcsend, enyhén felhős vagy derült ég jellemezte. Az észlelések alkalmával kifejezetten meleg volt, a léghőmérséklet kiegyensúlyozottan $+9{ }^{\circ} \mathrm{C}$ és $+15^{\circ} \mathrm{C}$ közé esett. 
A vegetáció még nem indult meg, de a szántókon már fedettséget eredményeztek a termesztett növények, az őszi káposztarepce, az őszi búza és a lucerna alacsony, a tavaszi árpa pedig éppen kelt.

Rendkívüli időjárási helyzet: nem volt.

6. táblázat: A környezeti jellemzők változása 2008 és 2012 között

Table 6: Change of weather conditions between 2008 and 2012

\begin{tabular}{ccccccc}
\hline $\begin{array}{c}\text { Felmérés időpontja } \\
\text { Survey date }\end{array}$ & $\begin{array}{c}\text { Felmérés ideje (óra/perc) } \\
\text { Survey time } \\
\text { (hour/minute) }\end{array}$ & $\begin{array}{c}\text { Léghömérséklet } \\
\text { Temperature } \\
\left({ }^{\circ} \mathrm{C}\right)\end{array}$ & $\begin{array}{c}\text { Felhőzet } \\
\text { Cloud } \\
(\%)\end{array}$ \\
\hline $\begin{array}{c}\text { Átlag nap/ } \\
\text { Average day }\end{array}$ & $\begin{array}{c}\text { Kezdés (min.) } \\
\text { Beginning }\end{array}$ & $\begin{array}{c}\text { Zárás (max.) } \\
\text { Closing }\end{array}$ & $\begin{array}{c}\text { Min./ } \\
\text { Min. }\end{array}$ & $\begin{array}{c}\text { Max./ } \\
\text { Max. }\end{array}$ & $\begin{array}{c}\text { Min./ } \\
\text { Min. }\end{array}$ & Max./ \\
\hline 2008.10 .03 & 19.17 & 21.49 & $+11,0$ & $+19,5$ & 30 & 80 \\
2009.04 .01 & 20.12 & 23.47 & $+9,0$ & $+15,0$ & 0 & 45 \\
2009.11 .29 & 16.56 & 20.32 & $+4,0$ & $+12,0$ & 45 & 100 \\
2010.03 .30 & 20.13 & 23.15 & $+9,0$ & $+12,0$ & 0 & 50 \\
2010.10 .07 & 19.13 & 22.42 & $+5,5$ & $+13,5$ & 0 & 100 \\
2011.04 .05 & 20.10 & 00.04 & $+5,0$ & $+12,0$ & 0 & 100 \\
2011.10 .18 & 18.42 & 21.36 & 0,0 & $+15,0$ & 0 & 100 \\
2012.03 .13 & 18.48 & 21.29 & $+2,0$ & $+8,0$ & 0 & 70 \\
2012.10 .25 & 18.30 & 21.13 & $+8,0$ & $+12,0$ & 20 & 100 \\
\hline
\end{tabular}

3. 2009 ösz-(2009. november 26., 30., december 1.)

Az évet száraz tavasz és csapadékos ősz jellemezte, az évi középhőmérséklet $1,8{ }^{\circ} \mathrm{C}$-al magasabb volt a sok éves átlagnál. 2009. október 27-étől november 22-ig több hullámban, összesen 125,4 mm csapadék esett Dévaványa térségében, így annyira átázott a talaj, hogy november utolsó napjaiban is csak jelentős kockázattal kezdhettünk neki a számlálásnak. A Szilasokon már vadászott a vadásztársaság, a mintaterületen 40 mezei nyulat ejtettek el.

A felmérések alkalmával minden vizes volt, a változó felhőzet mellett szélcsendes, gyengén szeles idöszakok váltották egymást, a mért léghőmérséklet $+4{ }^{\circ} \mathrm{C}$ és $+12{ }^{\circ} \mathrm{C}$ között változott.

A szántókon már megjelent az őszi búza és az őszi káposztarepce (7. táblázat), de a gyenge növekedés miatt az észlelési távolságot nem kellett módosítani.

Rendkívüli időjárási helyzet: nem volt.

A tavaszi időszakban rendkívüli és folyamatos csapadék volt jellemező a DélTiszántúl időjárására. A földutakon sok helyen a közlekedés rendkívüli nehézséget jelentett (5. ábra). A Réhelyi mintaterületen nem lehetett végigmenni, az út a téli erőgépi igénybevétel miatt terepjáróval gyakorlatilag járhatatlan volt. Az észlelést is sok helyen nehezítette a terepjáró erőltetett haladása. 
7. táblázat: A vegetáció magasságának $(\mathrm{mm})$ változása 2008 és 2012 között Table 7: Change of vegetation height $(\mathrm{mm})$ between 2008 and 2012

\begin{tabular}{ccccc}
\hline $\begin{array}{c}\text { Felmérés időpontja } \\
\text { Survey date }\end{array}$ & \multicolumn{2}{c}{$\begin{array}{c}\text { Őszi káposztarepce/ } \\
\text { Oil seed rape }\end{array}$} & \multicolumn{2}{c}{$\begin{array}{c}\text { Ószi búza/ } \\
\text { Winter } \text { wheat }\end{array}$} \\
\hline $\begin{array}{c}\text { Átlag nap/ } \\
\text { Average day }\end{array}$ & $\begin{array}{c}\text { Vegetáció/ } \\
\text { Vegetation }\end{array}$ & $\begin{array}{c}\text { Magasság/ } \\
\text { height }\end{array}$ & $\begin{array}{c}\text { Vegetáció/ } \\
\text { Vegetation }\end{array}$ & $\begin{array}{c}\text { Magasság/ } \\
\text { height }\end{array}$ \\
\hline 2008.10 .03 & Foltos & $2-4$ & Foltos & $4-6$ \\
2009.04 .01 & Zárt & $4-6$ & Zárt & $6-8$ \\
2009.11 .29 & Foltos & $0-2$ & Zárt & $2-4$ \\
2010.03 .30 & Zárt & $2-4$ & Zárt & $8-10$ \\
2010.10 .07 & Foltos & $4-6$ & - & 0 \\
2011.04 .05 & Zárt & $4-6$ & Zárt & $6-8$ \\
2011.10 .18 & Foltos & $4-6$ & - & 0 \\
2012.03 .13 & Foltos & $4-6$ & Foltos & $6-8$ \\
2012.10 .25 & Zárt & $8-10$ & Foltos & $4-6$ \\
\hline
\end{tabular}

4. 2010 tavasz-(2010. március 29., 30., 31.)

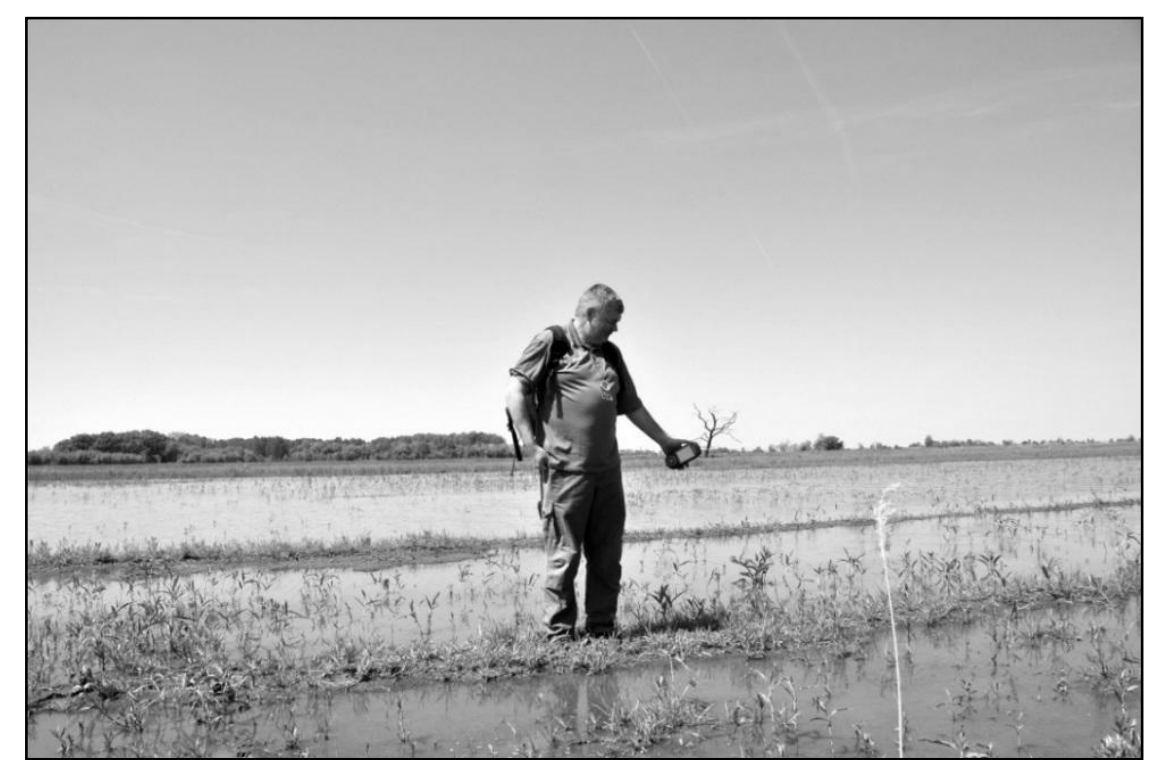

5. ábra: Belvízi elöntés a felső térszintekre is jellemző volt 2010-ben

- Túzokvédelmi Mintaterület, 2010. április 30. (Fotó: CZIFRÁK G.)

Figure 5: Even higher situated areas were flooded in 2010 - Great Bustard Conservation Site, 30 April 2010 (Photo: G. CZIFRÁK)

A felmérések alkalmával a léghőmérséklet $+9{ }^{\circ} \mathrm{C}$ és $+12{ }^{\circ} \mathrm{C}$ közé esett, szélcsend, illetve gyenge szellő jellemezte a légmozgást. A harmadik számlálási napon a felmérést megelőzően, délután jelentős csapadék esett, amely részben inaktivitást, részben ködfoltokat eredményezett.

A gyepeken a növényzet még nem indult növekedésnek, de a szántókon megjelenő mezőgazdasági kultúrák már fedettséget okoztak. Az őszi búza állományát 8-10 cm-es, az őszi káposztarepcéjét 2-4 cm-es magasság jellemezte.

Rendkívüli időjárási helyzet: hűvös, csapadékos, belvizes tavasz. 
A 2010. március 29-ei számláláskor figyeltünk meg egy 1-2 hetes kis nyulat a kis parcelláknál (T6) (6. ábra), de a három nap alatt csak ebben az egy esetben fordult elő.

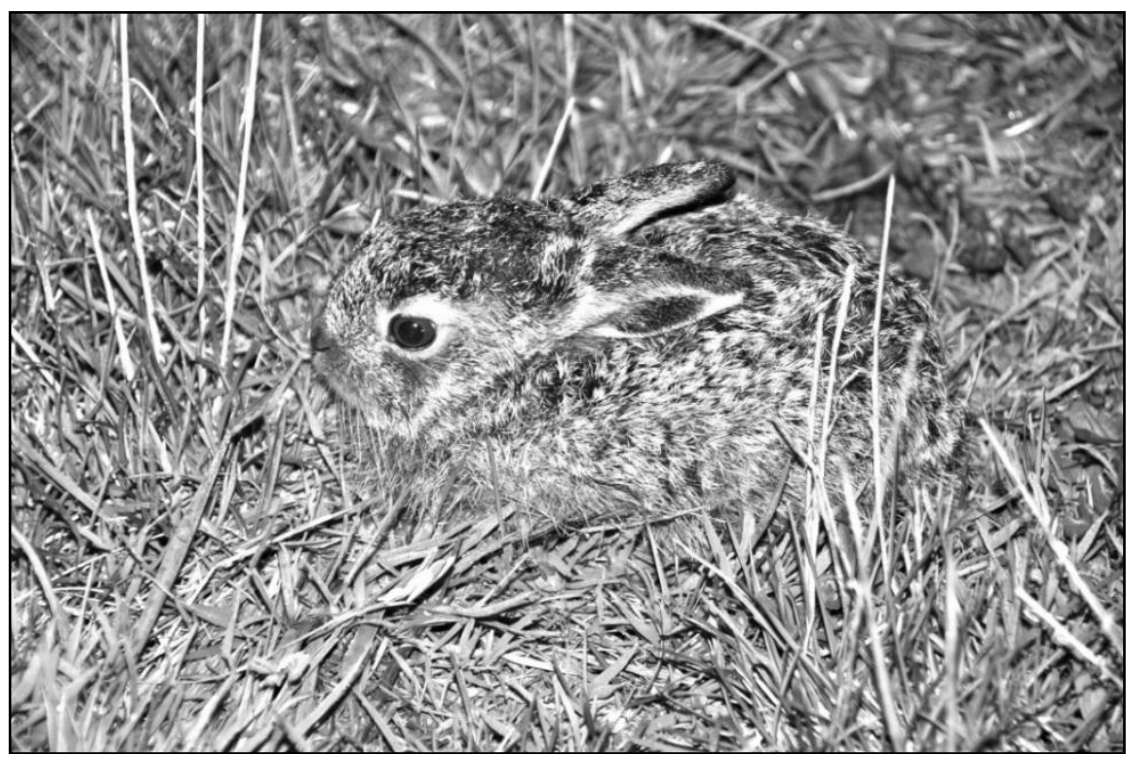

6. ábra: Fiatal mezei nyúl a Túzokvédelmi Mintaterületen (2010.03.29.) (Fotó: TIRJÁK L.)

Figure 6: A leveret on the Great Bustard Conservation Site (Photo: L. TIRJÁK)

\section{2010 ösz-(2010. október 4., 6., 11.)}

A 2010-es esztendő eddig példa nélkül álló, rendkívüli csapadék mennyiséget hozott. A 2009-2010-es téli csapadék magas értéke mindenfelé belvízi elöntéseket okozott, melyet a mennyiséget tekintve szintén kimagasló Medárd-napi esőzés követett (éves csapadék 769 $\mathrm{mm})$. A folyamatos esőzések egyedülálló belvízi helyzetet eredményeztek Dévaványa térségében. Példaként említhető, hogy a legnagyobb dévaványai mezőgazdasági gazdálkodó az Agro-Déva Kft., a 2009-2010-es gazdasági évben cca. 600 hektár szántóföldi területet nem tudott bemüvelni. Az őszi időszakban több napsütéses időszak kialakult, így az első száraz ciklus alkalmával el tudtuk végezni a számlálásokat.

Az első felmérési napot szemerkélö eső, a másodikat és harmadikat derült ég és szélcsendes időjárás jellemezte. Az észlelések során mért hőmérséklet $+5,5{ }^{\circ} \mathrm{C}$ és $+13,5{ }^{\circ} \mathrm{C}$ közé esett.

A sok csapadék és részben a mezőgazdasági munkák elmaradása következtében sok helyen magas volt a szegélynövényzet, a magas lucerna és ugarvegetáció, illetve a még találkozni lehetett lábonálló napraforgóval, cirokkal és kukoricával. Ebben az időszakban a magas növényzet néhány ponton csökkentette a terület megfelelö belátását.

A kedvező ősz eleji csapadéknak köszönhetően a repce már megindult, a magasság 46 centimétert ért el. Az őszi búza még nem kelt ki.

Rendkívüli időjárási helyzet: egész évben folyamatos csapadék, kimagasló Medárd-napi esőzéssel, éves kimagasló csapadékkal.

A Békés Megyei Mezőgazdasági Szakigazgatási Hivatal Földmüvelésügyi Igazgatósága 2010. november 18-án felhívást tett közzé a rendkívüli időjárási körülmények következményi miatt. A Hivatal nyomatékosan kérte a vadgazdálkodókat, hogy kíméljék az apróvadállományt, hiszen sok helyen a törzsállomány fennmaradása került veszélybe (VALLER, 2010). 


\section{2011 tavasz - (2011. április 4., 5., 6.)}

A 2011-es esztendő első 3 hónapjában alig volt csapadék, de az elmúlt évben kialakult belvízi elöntések még most is uralták Dévaványa környékét.

A három, egymást követő napon végzett számlálások idején napsütés és frontátvonulás váltakozott. Az első felmérési napon a hőmérséklet $+12{ }^{\circ} \mathrm{C}$ volt, a második napon radikálisan visszaesett $+5{ }^{0} \mathrm{C}$-ra, majd harmadik nap a $+15{ }^{0} \mathrm{C}$-ot is elérte a léghőmérséklet.

A mezőgazdasági kultúrák alig indultak meg, az őszi búza 6-8 centiméteres, a repce 46 centiméteres magasságot ért el. Ennek ellenére a növényzettel borított szántókon is már fedettséget eredményezett a termesztett növények jelenléte, így mind a szántókon, mind a kissé megindult gyepeken azonos észlelési távolsággal számoltunk.

Rendkívüli időjárási helyzet: nem volt.

\section{2011 ösz - (2011. október 17., 18., 19.)}

A 2011-es esztendő időjárását a júliusi esőzéseket követő lehűlés, majd rendkívüli csapadékhiány, szárazság jellemezte. Gyakorlatilag érdemi nyárvégi-őszeleji csapadék nem esett.

Az első két észlelési napot szélcsend, derült ég, $0{ }^{0} \mathrm{C}-+6{ }^{0} \mathrm{C}$ közötti hőmérséklet jellemezte. A harmadik nap nyugatról front érkezett, beborult, közepes szél és mintegy $+15{ }^{\circ} \mathrm{C}$ fokos léghőmérséklet alakult ki az észlelési időszakra, csapadék ekkor még nem esett.

A szárazság következményeként a zöld növényzettel fedett területek (gyep, lucerna, ugar) többségében leszáradtak, kivéve néhány nedvesebb termőhelyi foltot. A szántott, tárcsázott, illetve frissen vetett őszi kalászosok táblái szintén teljesen szárazak, a felületük többségében porhanyós volt és erősen porzott. Az őszi kalászosok még nem keltek ki, az őszi káposztarepce vetések néhol kielégítően fejlődtek, friss zöld tömeget adva a 4-6 cm-es magasságot is elérték. Két helyen kukorica- és ciroktarló is megjelent a mintaterületen, bár a kukorica nem jellemző, de az elmúlt év csapadékos időszakának köszönhetően több helyen megpróbálkoztak a termesztésével.

Rendkívüli időjárási helyzet: rendkívül száraz év volt, azonban a tenyészidőszaki „Medárd-napi” csapadékciklus részben mérsékelte a nyárvégi aszálykáros hatásait. Az évi csapadékmennyiség 35\%-kal volt kevesebb a térségre jellemző sokéves átlagnál.

\section{2012 tavasz-(2012. március 12., 13., 14.)}

A téli csapadék részlegesen sem tudta pótolni a 2011 évi száraz nyárutó és száraz ősz következtében kialakult általános csapadékhiányt. Külön meg kell említeni a 2012. február 2-án leesett hómennyiséget, amely egy tartós, fagypont alatti 4 hetes hideg ciklussal párosult. Az egybefüggő 30-40 centiméteres hótakaró a táplálkozó helyek teljes befedésével különleges kihívást jelentett az élővilág számára (7. ábra), melynek hatásai egy olyan zárt rendszer esetében, mint a Túzokvédelmi Mintaterület kiemelten jelentkezhetnek. A túzokok számára mintegy 150-200 hektáron letolták a havat a repce és egyéb táplálékforrást biztosító földekröl a térségben, a túzokcsapatok nem vonultak el. 


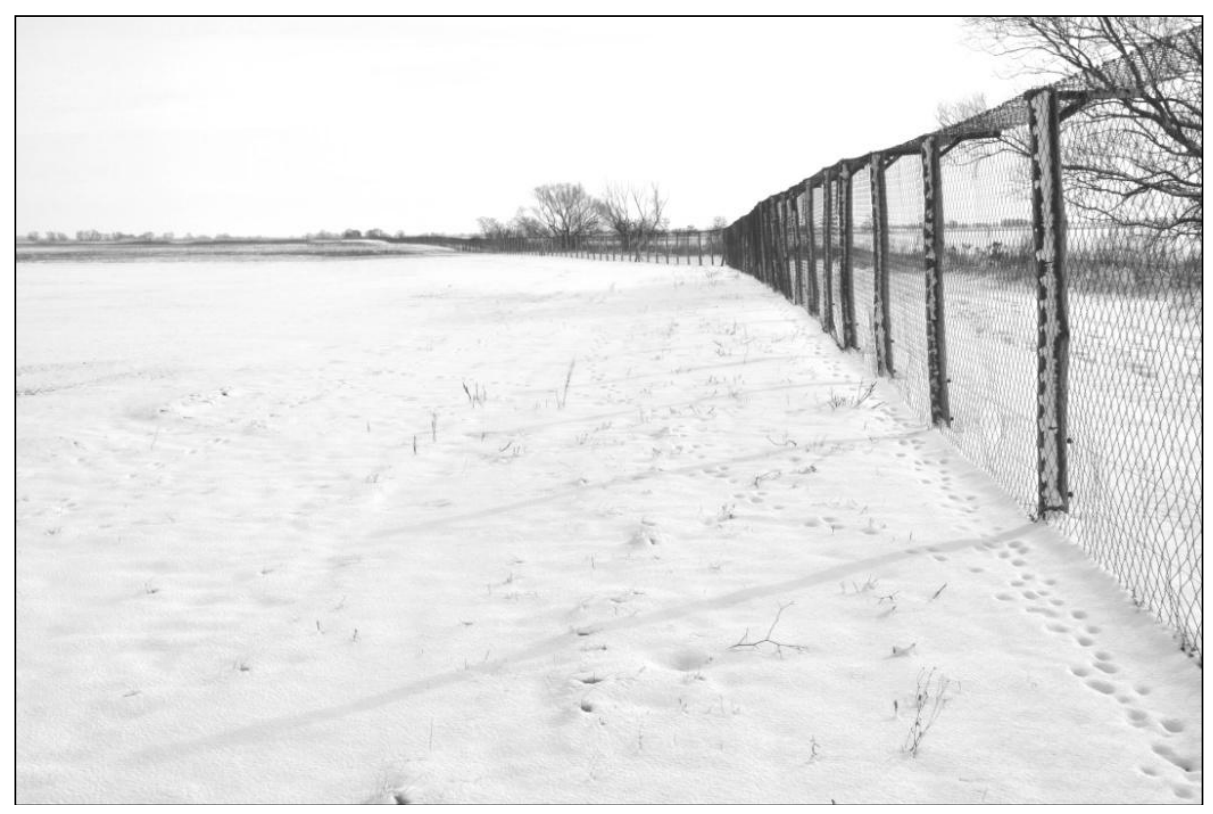

7. ábra: Jól kivehető a mezei nyulak sürüsödő nyomai a kerítés belső oldalán a téli havas időszakban (2009.02.15) (Fotó: TIRJÁK L.)

Figure 7: Dense tracks of Brown Hare are clearly visible on the inner side of the fence in the snowy winter period (Photo: L. TIRJÁK)

A három, egymást követő napon végzett számlálások idején alapvetően derült volt az ég, melyet egy kisebb felhőátvonulás színesített. A léghőmérséklet $+2{ }^{0} \mathrm{C}$ és $+8{ }^{0} \mathrm{C}$ között változott.

Rendkívüli időjárási helyzet: februári tartós, 4 hétig elhúzódó, 30-40 centiméteres hótakaró.

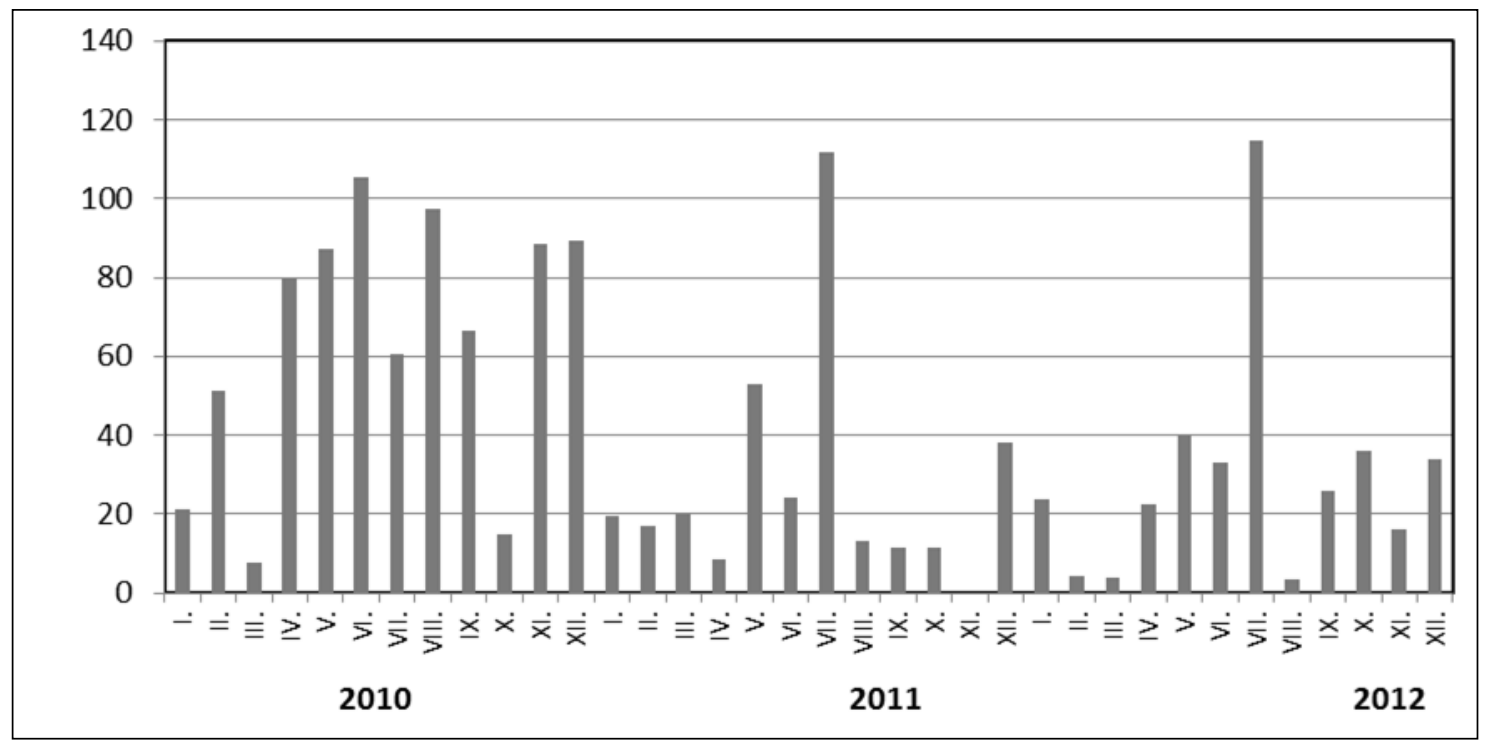

8. ábra: A havi csapadékösszeg (mm) alakulása 2010 és 2012 között (Dévaványa)

Figure 4: Monthly precipitation between 2010 and 2012 (Dévaványa) 


\section{2012 ösz-(2012. október 24., 25., 26.)}

A 2012-es év időjárását különösen nagy szélsőségek jellemezték (8. ábra). Első meghatározó időjárási elem a 2011. február 2-án leesett jelentős hómennyiség, amely egy tartós, 4 hetes fagypont alatti hideg ciklussal párosult és egybefüggő 30-40 centiméteres teljes hótakarót eredményezett. Meg kell jegyezni, hogy ennek ellenére már februárban csapadékhiány alakult ki, mivel a területet fedő hótakaró „,porhó” volt, így víztartalma durván a felét tette ki az átlagos mennyiségnek $(30 \mathrm{~cm}-15 \mathrm{~mm})$. Ezt követte egy rendkívül száraz tavasz, nyárelö, melynek következtében Dévaványa környékén alig lehetett kaszálható gyepet találni. Június végére - július elejére alakult ki egy viszonylag rövid csapadékos ciklus, amely segített abban, hogy bár érdemi kaszáló nem volt, de a gyepek legeltetésre alkalmasak legyenek, ne égjenek ki teljesen. A nyár vége és az ösz eleje ismét rendkívül száraz volt, érdemi csapadék nem esett. Szeptember végén alakult ki egy rövid csapadékos időszak, amely az elvetett őszi káposztarepce, illetve az őszi gabona kelését, a lucerna, az ugar és a gyepek sarjadzását segítette elő. Az őszi, rendes csapadékot hozó időjárási frontok a számlálást követően, október végén érkeztek meg.

$\mathrm{Az}$ észleléseket három, egymást követő napon sikerült teljesíteni. Az időjárást szélmentesség, csapadékmentesség, vékony magas felhőzeti mozgás, +8 és $+12 \mathrm{C}$ fok közötti enyhe hömérséklet jellemezte.

Az őszi káposztarepce vetések jól fejlödtek, magasságuk elérte a 8-10 centiméteres magasságot. Az őszi kalászosok általában alig keltek ki, a kelő állományokat is erős foltosság jellemezte, maximum 4-6 cm-es magasságot értek el. Magas, még betakarítatlan kultúra (napraforgó, kukorica, cirok), amely a belátást zavarta volna, az idei esztendőben nem volt.

Rendkívüli időjárási helyzet: nyár végi, ősz elejei szárazság.

\subsection{A MEZEINYÚL-ÁLLOMÁNY ÖSSZEHASONLÍTÓ VIZSGÁlATA}

\subsubsection{A mintaterületek kijelölése}

A vizsgálat során három mintaterület került meghatározásra (9. ábra, 8. táblázat). $\mathrm{Az}$ első mintaterület a Túzokvédelmi Mintaterületen, a másik két külső kontrollterület pedig hasonló élöhelyi arányokat képviselö közeli területrészeken lett kijelölve.

A kijelölést az alábbi szakmai szempontok határozták meg:

- A mintaterületeken az előforduló élőhelyek (gyep, ugar, lucerna, szántó) aránya közel azonos legyen.

- A vadászati hasznosítás jelenléte vagy hiánya, illetve a róka előfordulása vagy hiánya váltakozzon a három mintaterületen.

- Az éjszakai reflektoros állománybecslés mintavonalai nehéz időjárási körülmények között is járhatók legyenek.

- A mintaterület nagysága 50 és 150 hektár közé essen, a mintavétel hossznak minimum 4000 méternek kell lenni.

- A mintaterületek közel legyenek egymáshoz, de ne legyenek szomszédosak, hogy a felmérés során megzavart mezei nyulak ne tudjanak átmenni másik mintaterületre, ki legyen zárva a kétszeres számlálás lehetősége. 


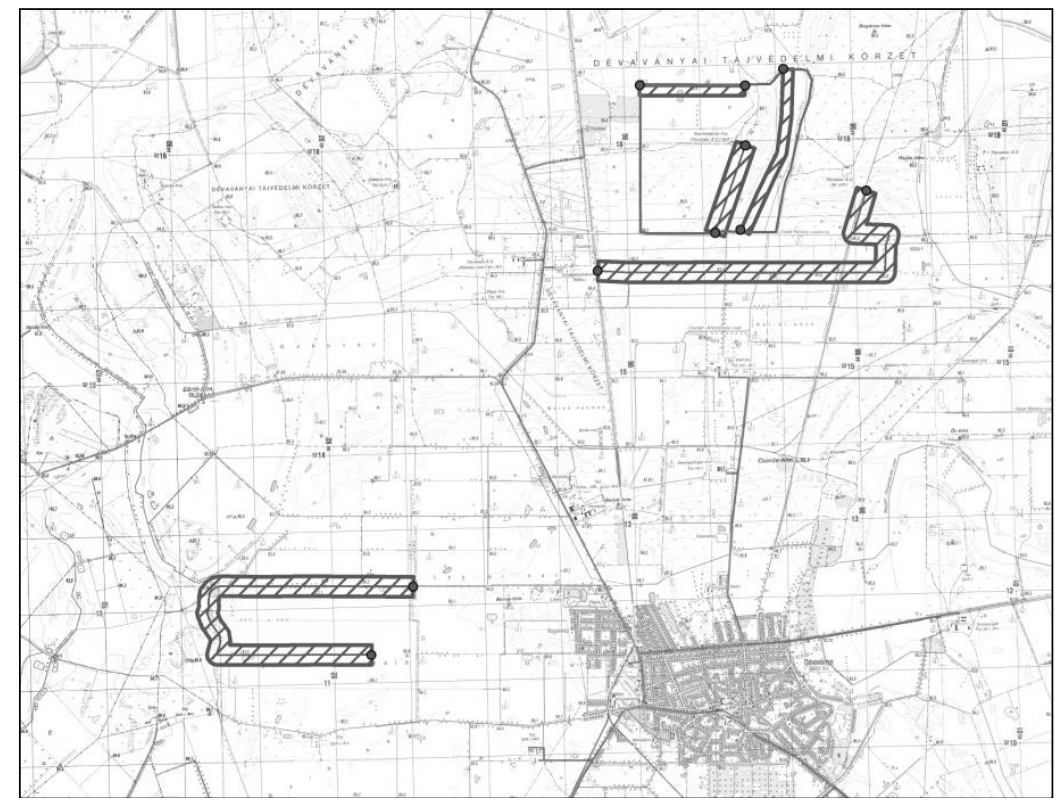

9. ábra: A mintaterületek elhelyezkedése Dévaványa térségében Figure 9: Distribution of sample sites in the Dévaványa area

8. táblázat: A kiválasztott három mintaterület fó jellemzői

Table 8: Main characteristics of the three study sites

\begin{tabular}{ccccc}
\hline $\begin{array}{c}\text { Sorszám } \\
\text { Nr. }\end{array}$ & $\begin{array}{c}\text { Mintaterület neve } \\
\text { Name of the site }\end{array}$ & $\begin{array}{c}\text { Róka } \\
\text { Fox }\end{array}$ & $\begin{array}{c}\text { Vadászati } \\
\text { hasznosítás } \\
\text { Hunting utilization }\end{array}$ & $\begin{array}{c}\text { Mintavonal } \\
\text { hossza (m) } \\
\text { Transect length }\end{array}$ \\
\hline 1. & Túzokvédelmi belsö mintaterület & - & $-*$ & 5300 \\
2. & Réhely mintaterület & + & - & 5300 \\
3. & Szilasok mintaterület & + & + & 5500 \\
\hline
\end{tabular}

*Megjegyzés: 2008 és 2009 öszén részleges, mintavétel jellegü gyérítés történt.

\subsubsection{Túzokvédelmi belső mintaterület}

A felmérések alkalmával végigjárt nyomvonal két különálló részből áll. Az első útvonal kezdőpontja a Túzokvédelmi Mintaterület délkeleti részén helyezkedik el, innen indul északi irányba és a kerítés széléig tart. A földút ebben az esetben inkább kitaposott gépkocsinyomnak felel meg, hiszen használatára csak a természetvédelmi kezelések alkalmával kerül sor, hossza 2200 métert tesz ki. A bal oldalt ritkás, a végén felszakadozó fasor és kaszálatlan gyep kíséri, jobb oldalt a T9-es tábla sávosan megmüvelt laposa húzódik. Itt merölegesen lefutó kisparcellák követik egymást, melyek 200-400 méter szélességüek, közöttük 20 méter széles gyepsávok, ún. „szőrmesgyék” fekszenek. A parcellákon őszi búza, őszi káposztarepce, lucerna és zöldugar váltakozik, a természetvédelmi célú vetésforgónak megfelelöen. Itt található egy részlegesen fás növényzettel borított bágergödör. A nyomvonal a kerítés előtt nyugatra fordul és a mintegy 600 méteres gyepbeékelődést elhagyva, a T6-os tábla északi szegélyén (10. ábra), a Túzokvédelmi Mintaterület kerítése mellett halad nyugati irányba mintegy 1300 méteren keresztül, a nyugati kerítésrész eléréséig. A T6-os tábla északdéli irányba tájolt, 100 méter széles parcellákból áll, melyeket „szőrmesgye” választ el. Itt is 
őszi búza, őszi káposztarepce, lucerna és zöldugar váltja egymást. Ezen a szakaszon - mivel a kerítés mellett halad - csak egyirányú észlelés történt délre, a T6-os tábla irányába. A belvizes időszakok 2 esetben is a kívülről történő felmérést tették szükségessé, ezekben az esetekben az észlelési távolságot újra meg kellett határozni.

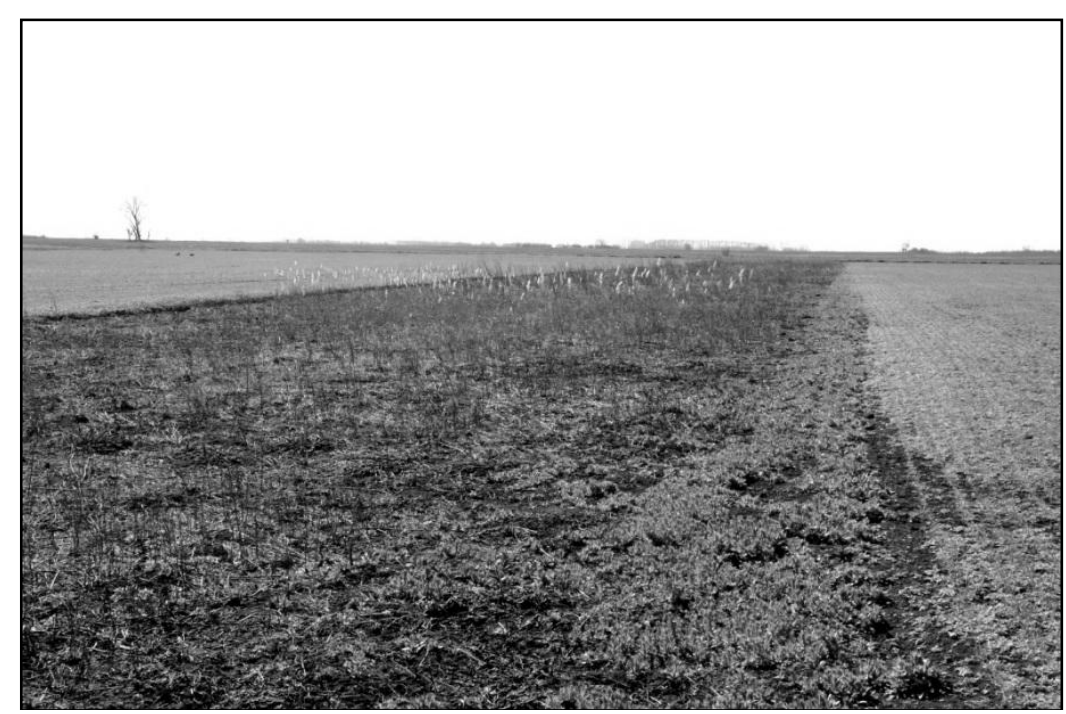

10. ábra: A Túzokvédelmi belső mintaterület (T6-os tábla) (Fotó: TIRJÁK L.) Figure 10: The Great Bustard Interior Sample Site (T6) (Photo: L. TIRJÁK)

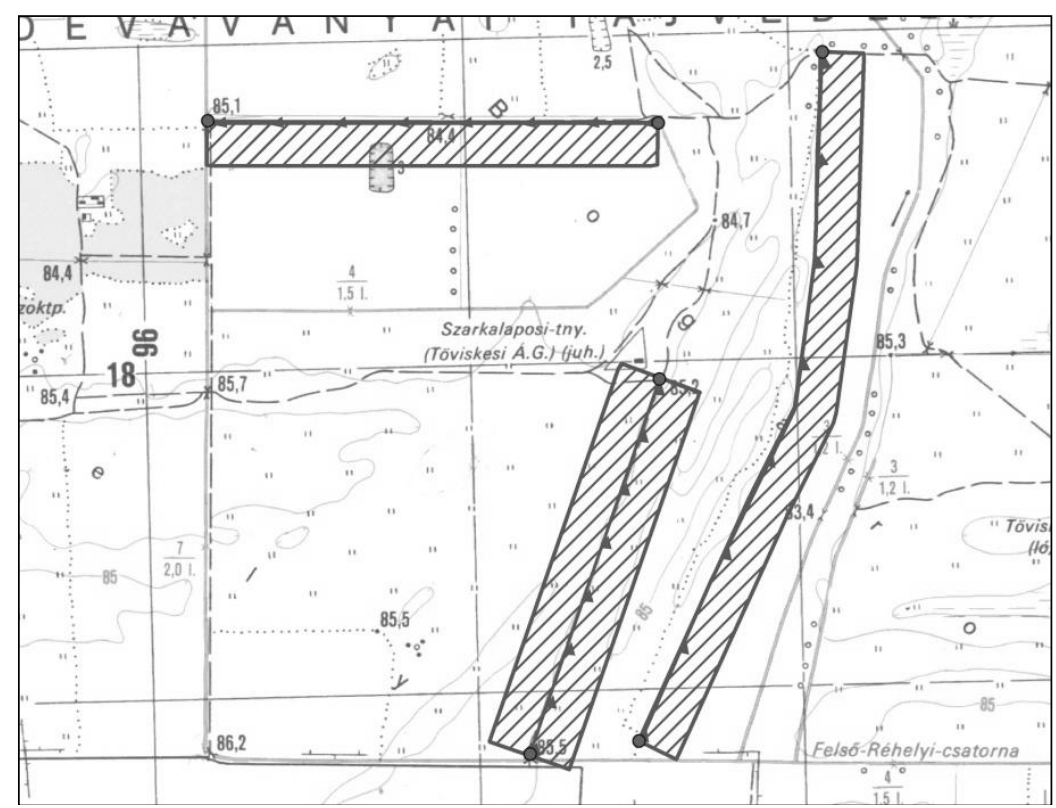

11. ábra. A Túzokvédelmi belső mintaterület bejárási útvonala

Figure 11: Survey route within the Great Bustard Interior Sample Site

A másik felmérési vonal a déli főkaputól indul északi irányba a kezelőépületig, végig gyepterületen halad egy kitaposott nyomot követve, balra kaszált vagy legeltetett a terület, míg jobb oldalon mélyfekvésü, gyakran vízzel borított kaszálatlan gyepterület fekszik. Ennek a mintavonalrésznek 1200 méter a hossza, de a túzok kihelyezések miatt gyakran kellett a 
végét elhagyni, hogy ne legyenek megzavarva a fiatal madarak. A mintavonal teljes hossza az 5300 méter (11. ábra), a mintaterület nagysága a vizsgálat időszakában 55,86 hektár és 62,36 hektár közé esett. A 3 mintaterület közül ez biztosítja a legkedvezőbb élőhelyi feltételeket a mezei nyúl számára.

\subsubsection{Réhely mintaterület (kontrollterület)}

A mintaterület fő jellemzője, hogy a terület döntő többsége a rendszerváltozáskor már védett volt, így nem került privatizációra. A vizsgálati időszakban a hasznosítást a valamikori mezőgazdasági termelöszövetkezet utódja, a dévaványai Agro-Déva kft. végezte, nagyüzemi rendszert müködtetve, így a nagytáblás szántóföldi müvelés volt az uralkodó (12. ábra). Ettől eltér a mintavonal utolsó 2 kilométere, ahol az agrár-környezetvédelmi program következtében a hasznosító lucernakultúrát alakított ki, a Nemzeti Park Igazgatóság gyepet, lucernát vetett, illetve fenntartotta a részben itt fekvő kisparcellás Fogolyvédelmi Mintaterületet.

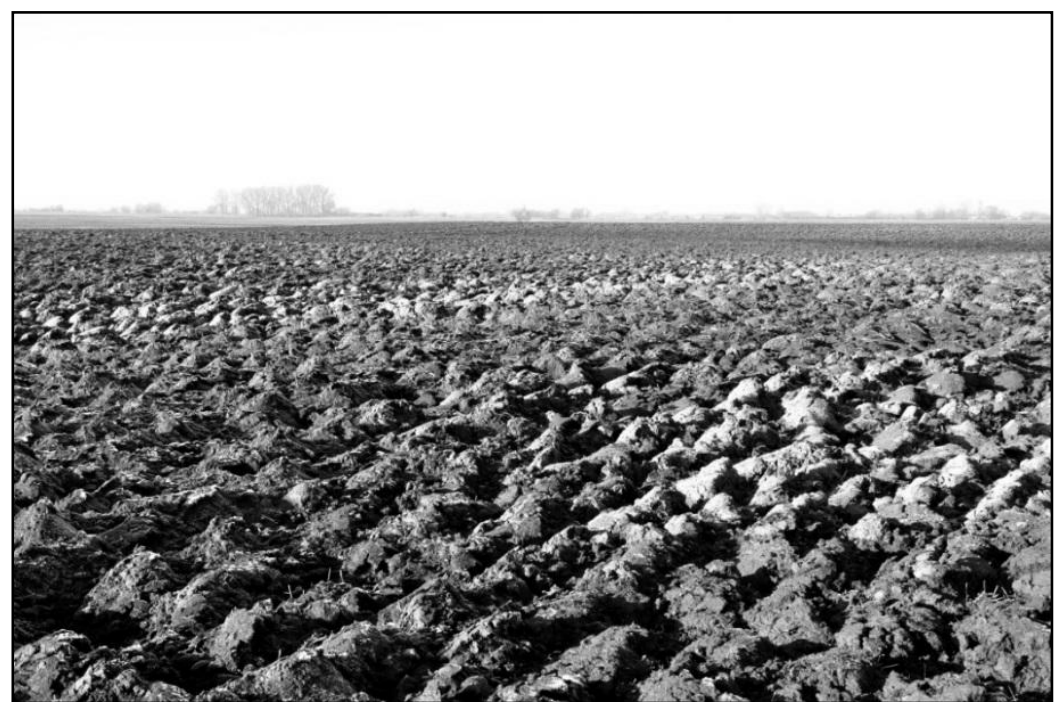

12. ábra: A Réhely mintaterület

Figure 12: The Réhely Sample Site

A mintavonal az Atyaszegi-legelö keleti földútján indul a Csikószín vonalában, északról déli irányba. Az első szakaszon mélyfekvésü, ritkán hasznosított ősgyep kíséri mindkét oldalon. Mintegy 600 métert követően eléri a Felső-Réhelyi csatornát, ekkor balra fordul, 500 méteren keresztül északra még az ősgyep mellett halad, de ekkor már jobbra megkezdődik a nagykiterjedésű szántóföldi táblák sorozata. Az első 1000 méteren lévő szántók a 80-as években még gyepek voltak, ekkor törték fel az értékes füves élőhelyeket. A mintavonal elöször délre, majd nyugatra fordul, nyomvonala a mezőgazdasági gazdálkodók által használt földúton halad. Jobbra és balra nagytáblás mezőgazdasági müvelés kíséri a mintavonal következő 1000 méterét. Ezeken a táblákon általában őszi gabonaféléket, őszi káposztarepcét és napraforgót termesztenek. Az utolsó 2000 méteren megváltozik a müvelés képe, megjelennek a kisebb táblakiosztások, a lucernások, a vetett gyepek és a zöldugarok, az útvonal végpontja a vasúti töltés melletti földút csatlakozása (13. ábra). A mintavonal teljes hossza az 5300 méter, a mintaterület nagysága a vizsgálat időszakában 120,34 hektár és 141,24 hektár közé esett. 


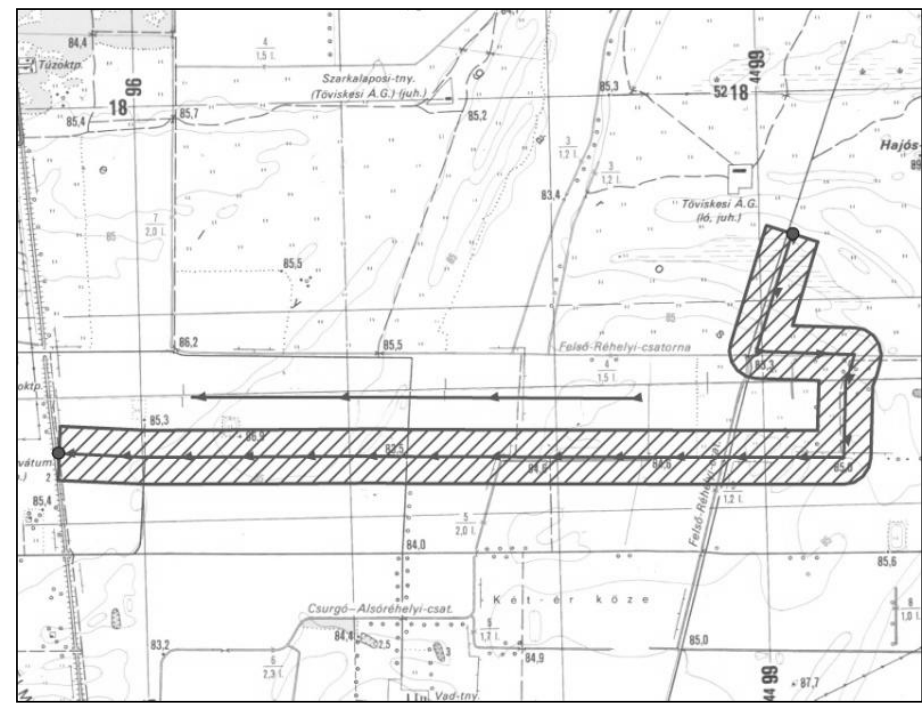

13. ábra: A Réhely mintaterület bejárási útvonala Figure 13: Survey route within the Réhely Sample Site

\subsubsection{Szilasok mintaterület (kontrollterület)}

Az érintett területrészt a rendszerváltásig a dévaványai Aranykalász MGTSZ. müvelte, azonban ezt követően több lépcsőben privatizálták. A magántulajdonba adás következménye a kisebb, különböző nagyságú táblák kialakulása volt, bár általánosságban a részleges egybemüvelés volt a jellemző. A kezdeti időben ezért az intenzív, nagytáblás mezőgazdasági használat volt az uralkodó gyakorlat.

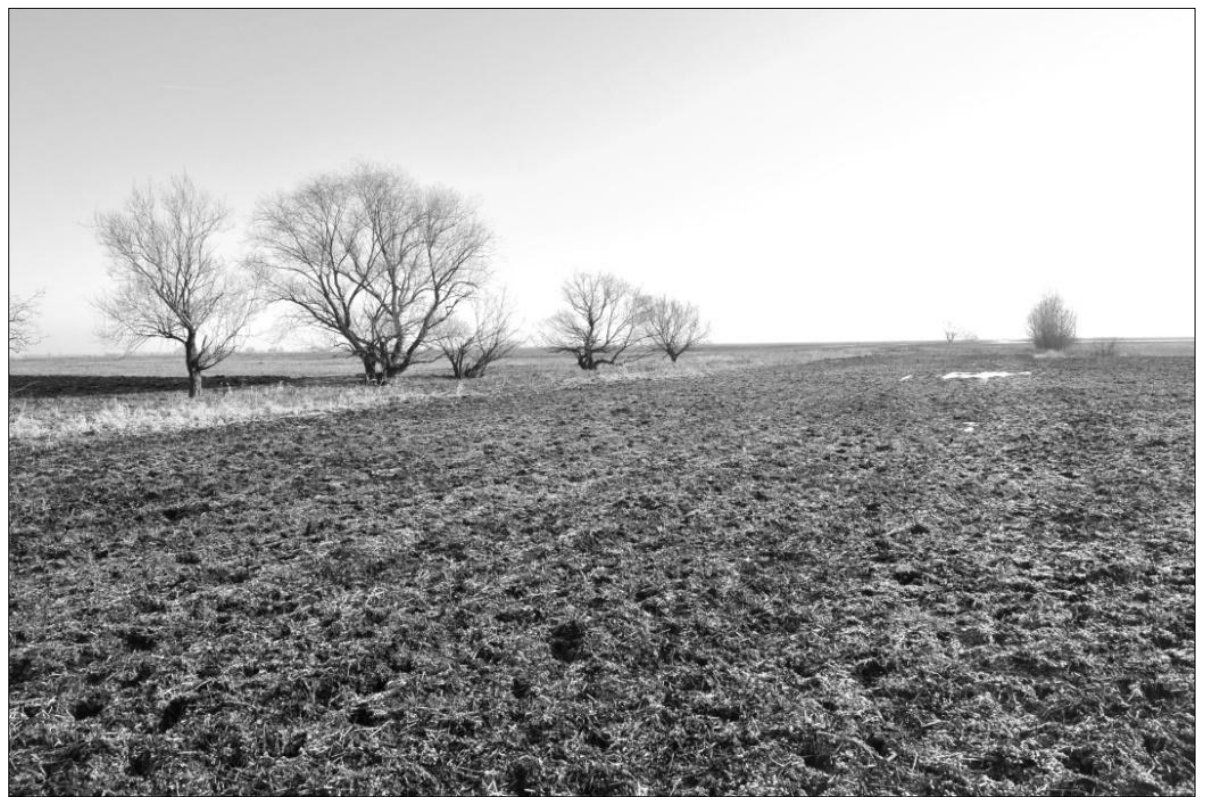

14. ábra: A Szilasok mintaterület bejárási útvonala

Figure 14: The Szilasok Sample Site

Ezen a helyzeten változtatott a 2004-ben induló „A túzok védelme Magyarországon” címü Life Program (LIFE04 NAT/HU/000109). Az európai uniós program keretében 2004 és 2006 között a Körös-Maros Nemzeti Park Igazgatóság a földek jelentős részét megvásárolta, 
ezeken lucernásokat telepített, gyepesítéseket hajtott végre és széleskörüen ugaroltatott. Ennek köszönhetően a kistáblás, változatos mezőgazdasági művelés vált általánossá a térségben (14. ábra).

A mintavonal - a gyep kivételével - védett területen kívül halad (15. ábra). A kezdőpont a „Villanykarós út” és az észak-déli irányban elhelyezkedő meliorációs csatorna metszéspontja. A nyomvonal a földúton, egyenes vonalvezetéssel halad nyugati irányba mintegy 2000 méteren keresztül. Ezen a szakaszon jobboldalt egybemüvelt, nagykiterjedésü mezőgazdasági táblákat találunk, ahol jellemzően őszi gabonát termesztenek. Baloldalt 100200 méter széles parcellák sorakoznak, köztük több vetett gyepsáv, ugarolt „nadrágszíj” és változatos képet mutató egyéb kultúra (pl. cirok) tünik fel. Ezt követően elérjük a védett pusztarészt, ahol a nyomvonal délre fordul, elhalad a valamikori állatgondozói épület mellett, átmegy egy észak-déli tájolású mély medermaradványon és miután 1800 métert halad az ősgyepen, eléri a szántóföldi zónát. Ekkor keletre fordul és 1800 méteren keresztül egy egyenes földutat követ.

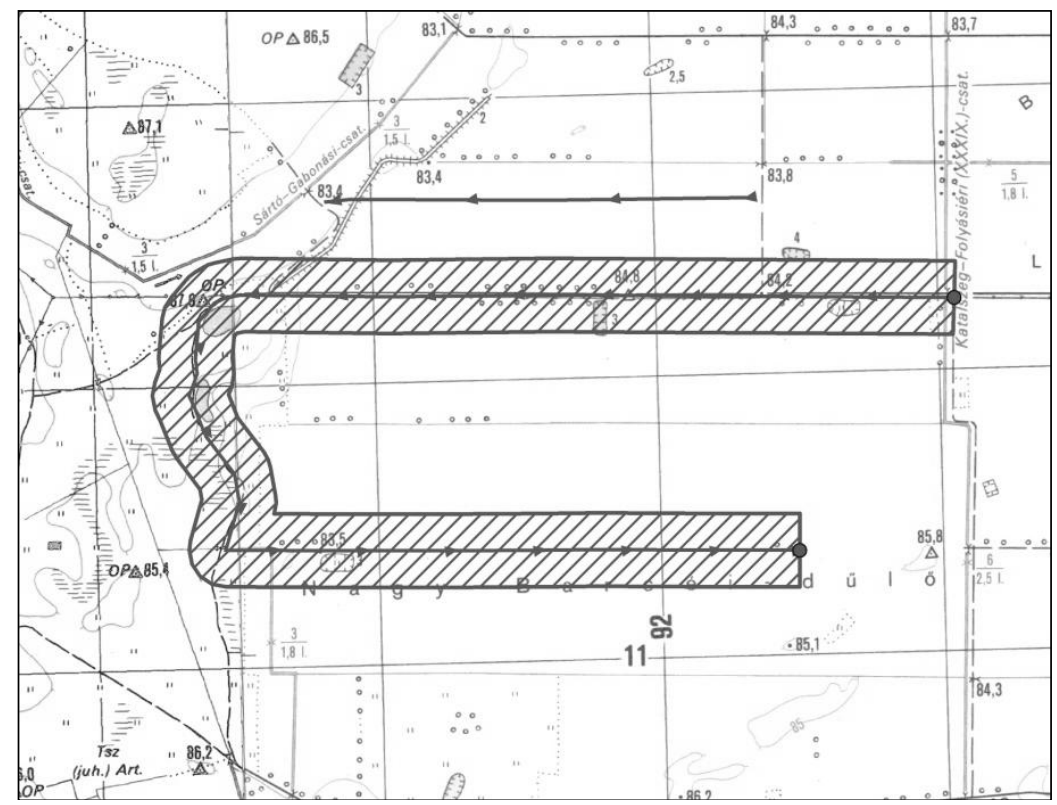

15. ábra: A Szilasok mintaterület

Figure 15: Survey route within the Szilasok Sample Site

Itt a táj, a mikrodomborzat változatossá válik, bágergödrök és itt-ott cserjeszinttel rendelkező fasorok is útba esnek. Az út baloldalát lucernások, ugarolt területek kísérik, jobb oldalt szintén elhelyezkednek lucernás és ugarolt parcellák, de itt már gabona-, illetve repcetáblák is feltünnek. A mintavonal teljes hossza 5500 méter, a mintaterület nagysága a vizsgálat időszakában 134,06 hektár és 146,09 hektár közé esett.

\subsubsection{A terepi felmérés módszertana}

A mezei nyulak állománysürüségének és populációnagyságának ismerete elengedhetetlen a szakszerü vadgazdálkodáshoz, a hasznosítás lehetőségeinek meghatározásához, bár az állatpopulációk nagyságának meghatározása nem könnyü feladat (DEMETER \& KovÁCS, 1991). A sávos becsléssel egy kitüzött, elnyújtott téglalap alakú mintaterületen előforduló mezei nyulak számát határozzák meg terepi bejárással. A 
mintaterületre befutó, kifutó, illetve elfekvő egyedek korrekciójával becsülik meg a leszámolt és a tényleges állománynagyságot (PIELOWSKI, 1969). Az egyedek befogása-jelöléseelengedése egy olyan nagy erőráfordítást igénylö becslési módszer, amely célzott, speciális kérdésekkel foglalkozó vizsgálatok esetén számos többletinformációt eredményezhet. Általában akkor indokolt ennek a módszernek a használata, ha az egyedszámon kívül más információra is szükségünk lehet (ABILDGARD et al., 1972).

Hazánkban a leggyakrabban használt módszernek számít az éjszakai, reflektoros sávos becslés a mezei nyulaknál, hiszen az idő- és munkaerő-ráfordítást tekintve a legelőnyösebb eljárásnak számít (FARAGÓ \& NÁHLIK, 1997). A megfelelő nagyságú mintaterületnek a megbízható számlálás, majd becslés érdekében jól belátható, nyílt mezőnek kell lennie (FRYLESTAM, 1981). A módszer alapja a sötétedés utáni éjszakai időszakban, reflektorral megvilágított nyulak számlálásán alapuló állománybecslés, ahol a kidülledő, jó fényvisszaverő szemek teszik lehetővé a megbízható azonosítást. A számlálás az egyenletes sebességgel haladó gépjármüből, reflektorral történik. A kiválasztott mintaterületnek a teljes vizsgált területhez hasonló arányban kell magába foglalnia az előforduló élőhelyeket, minimális nagyságának pedig a 10\%-ot kell elérnie (KovÁCs, 1986a, 1986b). A vadgazdálkodók tavaszi, többféle módszerrel végzett állománybecsléséi közel 30\%-kal kisebb állományadatokat eredményeztek, mint az éjszakai, sávos reflektoros becslés (BíRÓ \& SzEMETHY, 2002). A számlálást naplemente után érdemes $1 / 2-1$ órával kezdeni, mivel a nappali búvóhelyekről a táplálkozó területekre kiváltó egyedek ekkor a legaktívabbak. Az éjszaka hosszúságához igazodóan, az év különböző időszakában a napnyugtához viszonyított aktivitás folyamatosan változik (BíRÓ, 1996).

A felméréseinket az éjszakai reflektoros állománybecslés módszerével végeztük évente kétszer. Egy öszi (október első fele) és egy tavaszi (március vége - április eleje) időpontot választottunk, ami a szaporodási időszakot követő állománycsúcsnak és a szaporodási időszak előtti állományminimumnak felelt meg. Az állománybecsléseket minden esetben 3 alkalommal ismételtük meg, lehetőség szerint három egymást követő napon, melyet a kedvezőtlen időjárási körülmények némileg megváltoztathattak. A számlálások kezdete mindig a naplementét követően pontosan 1 órával, 2 órával, illetve 3 órával kezdődtek. A kezdő időpontok mindig úgy változtak a mintaterületeknél, hogy egy felmérési időszak alkalmával minden mintaterület minden időpontban sorra kerüljön. Egy-két esetben időbeli csúszást okoztak az elakadások, melyek a csapadékos időszakban kialakult vízállásoknak és a nehezen járható utaknak volt köszönhető.

A kitüzött mintavonalak hossza 5300 m és 5500 m közé estek, a nyomvonal általában mezőgazdasági földutakon vagy csapásokon haladt.

A felmérés során Ford Ranger 2AW, diesel-üzemü terepjárót használtunk, a számlálásban 4 fő vett részt, 1 fő irányító-adatrögzítő,1 fő gépjármüvezető és 2 fó észlelő. A felméréseket végző szakemberek a terepjáró jobb, illetve bal hátsó ülésen foglaltak helyet. A számlálásokat minden alkalommal ugyanazok a személyek végezték, ugyanabban a beosztásban. A felmérést végző személyek iskolai végzettsége: 2 fő erdőmérnök - vadászati szakmérnök; 1 fö erdőmérnök - agroökológus és 1 fö természetvédelmi mérnök. A használt vadászreflektorok típusa és teljesítménye minden esetben megegyezett (Kacsa, 12 V, $100 \mathrm{~W}$ ).

Előzetesen távolsági méréseket végeztünk a különbözö élöhelytípusokon (gyep, ugar, lucerna, szántó), mely segítségével megállapítottuk a későbbiekben használt észlelési távolságokat. A növényzettől mentes szántó, illetve a felmérési időszakokban különböző mértékben növényzettel fedett élőhelyek (gyep, ugar, lucerna) esetében az észlelési távolságok különböztek, a mért értékek eltértek. 
A számolás a kitűzött mintavonalakon $10 \mathrm{~km} / \mathrm{h}$ sebességgel haladva, a hátsó ülésekről folyamatos balra-jobbra észleléssel történt. A felmérés során használt adatlapokat elözetesen készítettük el, itt 100 méteres pontossággal feltüntetésre kerültek a balra, illetve jobbra található élőhelytípusok, a mezeinyúl-észlelések e szerint kerültek rögzítésre. Ahol a belátást valamilyen tereptárgy akadályozta (cserjesor, magas növényzet), ott a belátási távolságot csökkentettük.

Az észlelések alkalmával rögzítettük: a felmérés kezdete és vége, a felhőzet, a csapadék, a léghőmérséklet, a szélmozgás, illetve a mezei nyulak mellett az egyéb megfigyelt madár- és emlősfajok adatai.

A felmérések 2008 őszén kezdődtek és 2012 öszén fejeződtek be. A 9 felmérési időszak összesen 27 észlelési napot foglalt magába.

\subsubsection{A terepi adatok feldolgozása}

A felvételezés során elkülönítésre került a gyep, a lucerna, az ugar, a szántó (mélyszántás, tárcsázás), illetve amennyiben termesztett növény megjelent a szántón, akkor elkülönítettük a különböző mezőgazdasági kultúrákat: őszi búza, őszi káposztaperce, egyéb.

A megkülönböztetést a különböző mértékü beláthatóság és az élöhelytípusok sajátossága (pl. táplálkozó terület) indokolta. Ez tette lehetővé a későbbi élőhelypreferencia számítások elvégzését.

Ha egyes szakaszokon a növényzet magassága vagy egyéb tényező korlátozta a belátást, az észlelési távolságot ennek megfelelően csökkentettük. A mintavonal hossza és az észlelési távolságok szorzata adta a felmért terület nagyságát.

A három egymást követő számlálási nap egyedszámait átlagoltuk, majd a felmért terület nagyságával osztottuk, így kaptuk meg a mintaterület mezei nyúl állománysürüségét, ahol az értékeket hektáros területegységre vetítve adom meg.

A felmérések során gyüjtött adatokat a Microsoft Office Excel 2007 program felhasználásával értékeltem ki.

A mezeinyúl-állomány felmérése során a kijelölt mintaterületek adatsorainak, eredményeinek szignifikancia vizsgálatát F-próbával és t-próbával végeztem (SvÁB, 1973).

\section{Élőhelypreferencia meghatározása}

$\mathrm{Az}$ éjszakai számlálások során végrehajtott adatfelvételezések alkalmával folyamatosan feljegyeztük a mezeinyúl-előfordulások élőhelytípusonkénti megoszlását. Ezt a felmérési módszer 2010. évi kibővítése tette lehetővé, így 2010 és 2012 között összesen 18 észlelési nap adatai álltak rendelkezésre a vizsgálathoz. Összesen 3 tavaszi és 3 öszi adatsor került rögzítésre a felmérések során, így ezekből lehetett a különböző időszakok élőhelyhasználatát meghatározni.

Az előfordulási adatok értékelése során minden észlelést feldolgoztam, függetlenül attól, hogy a napnyugtát követő hányadik észlelési időpontban történt az észlelés. A változó éjszakai aktivitásból származó eltérések így kiegyenlítették egymást.

Az éjszakai számlálások alkalmával, a terepen észlelt előfordulási adatok az elöre elkészített Felmérési Adatlapon kerültek lejegyzésre, majd a feldolgozás első lépcsőjeként informatikai formátumban (Office Excel 2007) rögzítettem őket az adatbázisban. Ez a 
formátum tette lehetővé a későbbi táblázatos és a grafikonos megjelenítési formát. A statisztikai vizsgálatok során az állománysürüségi értékek közötti különbségek t-próba segítségével kerültek kiértékelésre.

Az élőhelykínálatot minden felmérési időszak első észlelési napján határoztuk meg végigjárva a mintavonalat és 100 méteres pontossággal rögzítve a táblahatárokat. Ebböl készült el az évente változó tartalmú, terepen használt Felmérési Adatlap. Az észlelési távolságok a mezőgazdasági kultúráknak megfelelően változtak, így a mintaterületen belüli élőhelytípusok nagyságát az érintett mintavonal hossza az észlelési távolság határozta meg.

A szántóföldi kultúráknál elkülönítettem a zöldugart, a lucernát, az őszi káposztarepcét, az őszi búzát és a feketeugart. Az egy-két esetben előforduló vetett gyepet a zöldugarhoz, a füves lucernát pedig a lucernához soroltam. A térség termőhelye nem kedvez a kukoricának, ezért előfordulása csak alkalomszerüen jelent meg, az őszi felméréseket érdemileg nem befolyásolta. 2010-től az adatrögzítések során a feketeugarnál elkülönítettük a durva barázdás, szántott táblákat és a tárcsázott vagy elsimított táblákat.

A mezei nyulak egyedenkénti észlelését a Felmérési Adatlapon élöhelytípusonként rögzítettük, így a tényleges élőhelyhasználat, illetve az élőhelyhasználathoz kapcsoló különböző mutatókat ebböl lehetett számítani.

Mind a három mintaterület esetében kiszámítottam az Ivlev-indexet $(E)$ (IVLEV, 1961):

$$
E_{i}=\frac{r_{i-} p_{i}}{r_{i+} p_{i}}
$$

ahol

$p_{\mathrm{i}}$ - élőhelytípus relatív kínálata

$r_{\mathrm{i}}$ - élőhelytípus relatív használata.

Mind a három mintaterület esetében kiszámítottam a Jacobs-indexet $(D)$ (JACOBS, 1974):

$$
D_{i}=\frac{r_{i}-p_{i}}{r_{i}+p_{i}-2 r_{i} p_{i}}
$$

ahol

$$
\begin{aligned}
& p_{\mathrm{i}} \text { - élőhelytípus relatív kínálata } \\
& r_{\mathrm{i}} \text { - élőhelytípus relatív használata. }
\end{aligned}
$$

A fenti két index felhasználásával értékeltem a mezei nyúl élőhelyválasztását a kijelölt mintaterületeken az állománybecslések időpontjaiban. 


\section{EREDMÉNYEK}

\subsection{A MEZEI NYÚL ÁLLOMÁNYÁNAK VÁLTOZÁSA A MINTATERÜLETEKEN}

\section{Túzokvédelmi belsö mintaterület}

A nyúlszámlálásra kijelölt területrész átlagosan 60,48 hektár nagyságú volt a vizsgált időszakban, a teljes Túzokvédelmi Mintaterületnek (397,95 ha) mintegy 15\%-át tette ki.

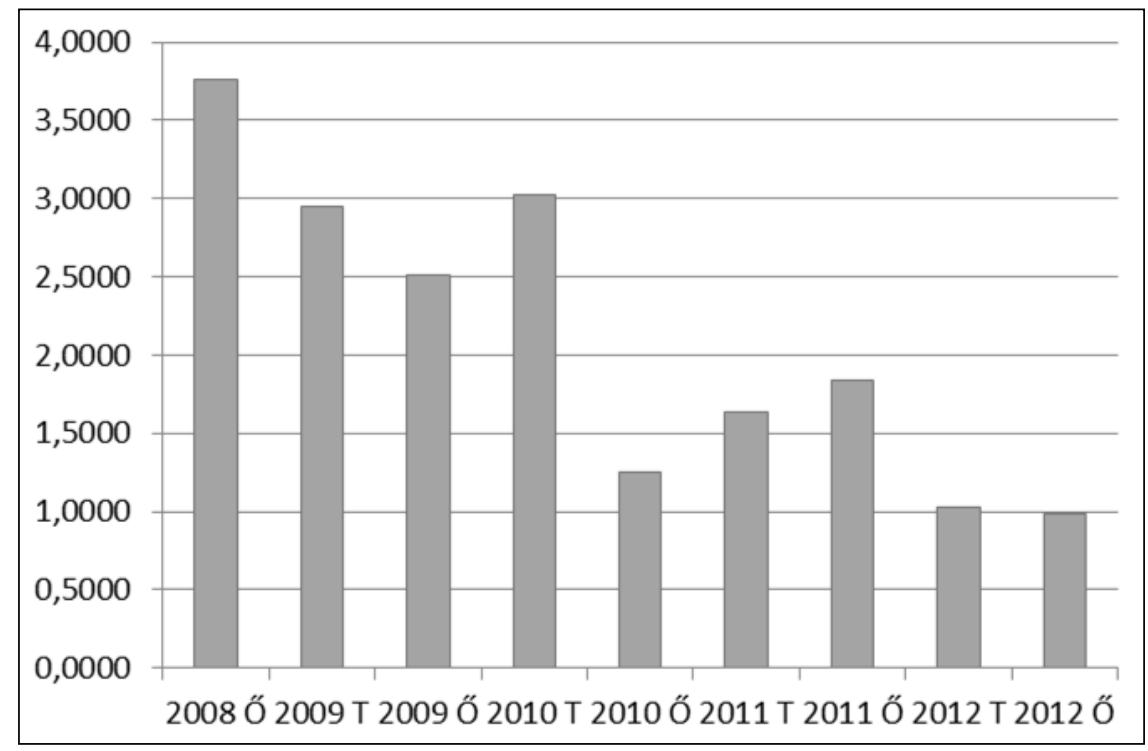

16. ábra: A mezei nyúl állománysűrüségének (db/ha) változása a Túzokvédelmi belső mintaterületen

Figure 16: Changes in Brown Hare population density on the Great Bustard Interior Sample Site

Az útvonal részben különböző élöhelytípusok határán halad, ezért a szegélyhatás itt is megjelenik. Száraz tavaszi időszakokban, mint a 2009 ősz - 2010 tavasz és a 2010 ősz - 2011 tavasz érzékelhető leginkább a szegélyhatás következménye. 2011 ösz - 2012 tavasz között a februári nyúlpusztulás miatt nem mutatkozik a tavaszi egyedszámnövekedés.

9. táblázat: A mezei nyúl állománysűrüségének változása a Túzokvédelmi belső mintaterületen Table 9: Changes in Brown Hare population density on the Great Bustard Interior Sample Site

\begin{tabular}{|c|c|c|c|c|c|c|c|}
\hline $\begin{array}{l}\text { Felmérés időpontja } \\
\text { Survey date }\end{array}$ & $\begin{array}{l}\text { 1.nap/ } \\
\text { 1. day }\end{array}$ & $\begin{array}{l}\text { 2.nap/ } \\
\text { 2. day }\end{array}$ & $\begin{array}{l}\text { 3.nap/ } \\
\text { 3. day }\end{array}$ & $\begin{array}{l}\text { Átlag/ } \\
\text { Average }\end{array}$ & $\begin{array}{l}\text { Mintaterület/ } \\
\text { Sample site }\end{array}$ & $\begin{array}{l}\text { Állománysűrüség/ } \\
\text { Population density }\end{array}$ & $\begin{array}{l}\mathbf{s}^{2} / \\
s^{2}\end{array}$ \\
\hline $\begin{array}{c}\text { Átlag nap/ } \\
\text { Average day }\end{array}$ & $\begin{array}{l}\mathbf{d b} / \\
\text { ind. }\end{array}$ & $\begin{array}{l}\mathbf{d b} / \\
\text { ind. }\end{array}$ & $\begin{array}{l}\mathbf{d b} / \\
\text { ind. }\end{array}$ & $\begin{array}{l}\mathbf{d b} / \\
\text { ind. }\end{array}$ & $\begin{array}{c}\text { ha/ } \\
h a\end{array}$ & $\begin{array}{c}\mathbf{d b} / \mathbf{h a} \\
\text { ind./ha }\end{array}$ & \\
\hline 2008.10 .03 & 230 & 248 & 225 & 234,33 & 62,36 & 3,76 & 0,04 \\
\hline 2009.04.01 & 169 & 153 & 172 & 164,67 & 55,86 & 2,95 & 0,03 \\
\hline 2009.11 .29 & 156 & 149 & 164 & 156,33 & 62,36 & 2,51 & 0,01 \\
\hline 2010.03.30 & 210 & 205 & 138 & 184,33 & 60,86 & 3,03 & 0,44 \\
\hline 2010.10 .07 & 83 & 74 & 69 & 75,33 & 59,90 & 1,26 & 0,01 \\
\hline 2011.04 .05 & 108 & 81 & 86 & 91,67 & 55,87 & 1,64 & 0,07 \\
\hline 2011.10 .18 & 118 & 114 & 112 & 114,67 & 62,36 & 1,84 & 0,00 \\
\hline 2012.03.13 & 63 & 72 & 57 & 64,00 & 62,36 & 1,03 & 0,01 \\
\hline 2012.10 .25 & 58 & 65 & 62 & 61,67 & 62,36 & 0,99 & 0,00 \\
\hline
\end{tabular}


A 2008. októberi észlelések során a 62,36 hektáros mintaterületen 248 példányt sikerült leszámolni $(3,76 \mathrm{db} / \mathrm{ha})$, ez volt az egész vizsgálati ciklusban a legmagasabb állománysürüségi érték (9. táblázat, 16. ábra).

A 2010-es év hüvös, csapadékos esztendő volt és a Túzokvédelmi Mintaterületen jelentős belvízi elöntéseket eredményezett, amely katasztrofálisan érintette a nyúlállományt, a Belső mintaterületen az egyedszám mintegy a felére csökkent (állománysürüség: $3,03 \mathrm{db} / \mathrm{ha}-1,26 \mathrm{db} / \mathrm{ha}$ ).

A fokozatosan stabilizálódó, növekvő állományt a 2012. februári hóesés vetette vissza újra. A leesett 30-40 centiméteres hótakaró nem olvadt el és mintegy négy héten keresztül egyenletesen borította a Túzokvédelmi Mintaterület. Az ekkor bekövetkezett pusztulást a mezeinyúl-állomány az év során nem tudta kiheverni, így az állománysürüség 2012 októberére $0,99 \mathrm{db} /$ ha-ra változott.

A 2008 ősze és 2012 ősze között a Túzokvédelmi belső mintaterület nyúlállománya lépcsőzetesen a negyedére esett vissza, a mintaterületen a mezei nyúl állománysűrüsége 3,76 db/ha-ról 0,99 db/ha-ra csökkent.

\section{Réhely mintaterület (kontrollterület)}

A mintaterületre a nagytáblás mezőgazdasági müvelés a jellemző, ezért a termesztett növények learatását követöen gyakran lép fel azonnali táplálékhiány, ami a mezei nyulak pusztulásához vezethet. Ezen a részen külön problémát okoz az intenzív napraforgótermesztés, ami akár fél éven keresztül is növényzetnélküli szántásokat eredményezhet. Ezért itt a téli időszakban a feketeugarok kiterjedése meghatározó lehet.

A felvételezések első évében, 2008 októberében kimagasló állománynagysággal találkoztunk a mintaterületen, átlagosan 106 egyedet számoltunk, ahol az állatok elsősorban a jól fejlett őszi búzán, másodsorban lucernán és zöldugaron táplálkoztak. Ekkor az állománysürüséget $0,77 \mathrm{db} /$ ha-ra becsültük (10. táblázat).

2009 öszén, a csapadékos ciklusoknak következtében a számlálásokat csak november utolsó napjaiban tudtuk elvégezni, akkor is a felmérést nehéz időjárási és terepi körülmények kísérték. Ennek az egyik következménye lehet, hogy a becslések jelentős kockázati tényezőt és esetleges alulbecsléseket hordozhatnak magukban.

10. táblázat: A mezei nyúl állománysürüségének változása a Réhely mintaterületen Table 10: Changes in Brown Hare population density on the Réhely Sample Site

\begin{tabular}{|c|c|c|c|c|c|c|c|}
\hline $\begin{array}{c}\text { Felmérés időpontja } \\
\text { Survey date }\end{array}$ & $\begin{array}{l}\text { 1.nap/ } \\
\text { 1. day }\end{array}$ & $\begin{array}{l}\text { 2.nap/ } \\
\text { 2. day }\end{array}$ & $\begin{array}{l}\text { 3.nap/ } \\
\text { 3. day }\end{array}$ & $\begin{array}{l}\text { Átlag/ } \\
\text { Average }\end{array}$ & $\begin{array}{l}\text { Mintaterület/ } \\
\text { Sample site }\end{array}$ & $\begin{array}{l}\text { Állománysürüség/ } \\
\text { Population density }\end{array}$ & $\begin{array}{l}\mathbf{s}^{2} / \\
s^{2}\end{array}$ \\
\hline $\begin{array}{c}\text { Átlag nap/ } \\
\text { Average day }\end{array}$ & $\begin{array}{l}\mathbf{d b} / \\
\text { ind. }\end{array}$ & $\begin{array}{l}\mathbf{d b} / \\
\text { ind. }\end{array}$ & $\begin{array}{l}\mathbf{d b} / \\
\text { ind. }\end{array}$ & $\begin{array}{l}\mathbf{d b} / \\
\text { ind. }\end{array}$ & $\begin{array}{c}\text { ha/ } \\
\text { ha }\end{array}$ & $\begin{array}{c}\mathbf{d b} / \mathbf{h a} \\
\text { ind./ha }\end{array}$ & \\
\hline 2008.10 .03 & 132 & 89 & 97 & 106,00 & 138,18 & 0,77 & 0,03 \\
\hline 2009.04.01 & 64 & 56 & 70 & 63,33 & 137,27 & 0,46 & 0,00 \\
\hline 2009.11.29 & 17 & 18 & 28 & 21,00 & 138,18 & 0,15 & 0,00 \\
\hline 2010.03 .30 & 0 & 0 & 0 & 0,00 & 0,00 & 0,00 & - \\
\hline 2010.10 .07 & 28 & 24 & 33 & 28,33 & 120,33 & 0,24 & 0,00 \\
\hline 2011.04 .05 & 29 & 23 & 29 & 27,00 & 136,17 & 0,20 & 0,00 \\
\hline 2011.10 .18 & 62 & 32 & 65 & 53,00 & 132,89 & 0,40 & 0,02 \\
\hline 2012.03 .13 & 48 & 43 & 44 & 45,00 & 141,23 & 0,32 & 0,00 \\
\hline 2012.10 .25 & 25 & 30 & 31 & 28,67 & 132,04 & 0,22 & 0,00 \\
\hline
\end{tabular}

2010 tavaszán a rendkívül csapadékos időszaknak köszönhetően ezen a mintaterületen nem tudtuk elvégezni a számlálásokat, ezért itt adathiány lépett fel. Az egész évben hűvös, 
átlag feletti csapadékmennyiség rendkívül érzékenyen érintette a mezeinyúl-állományt, ami a grafikonokon is jól nyomon követhető (17. ábra).

A 2012. februári egyhónapos havas időszak közvetett hatásait is megsínylette az állomány. A 2012. októberi számlálás alacsony egyedszámát az őszi számlálás idején a szántott területek rendkívül magas területi aránya (43\%) eredményezte.

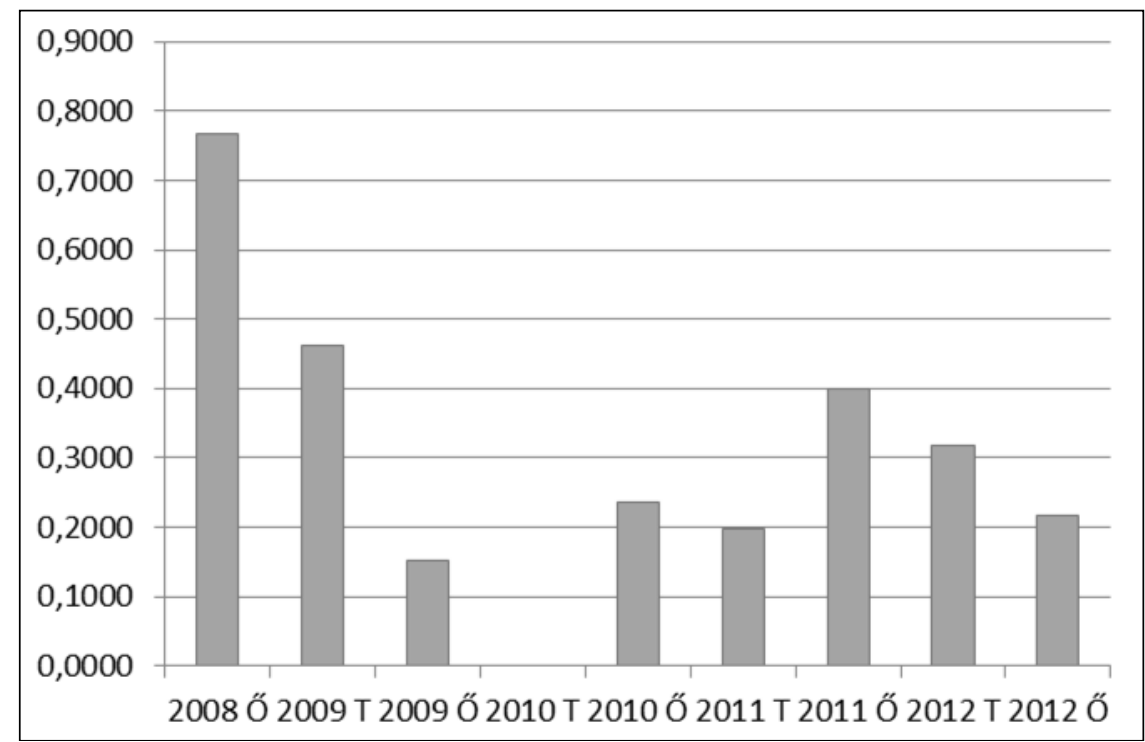

17. ábra: A mezei nyúl állománysürüségének $(\mathrm{db} / \mathrm{ha})$ változása a Réhely mintaterületen Figure 17: Changes in Brown Hare population density on the Réhely Sample Site

\section{Szilasok mintaterület (kontrollterület)}

Az érintett terület a 2004-ben kezdődött Túzok Life Programnak köszönhetően jelentős élőhelyfejlesztésen ment keresztül, ami a kisparcellákon történő müvelés elterjedését, illetve jelentős lucerna, gyep és zöldugar telepítést vont maga után. Az élőhelyfejlesztésnek az egyik haszonélvezője a mezei nyúl lett, a változásokra gyorsan reagált, és erős, magas egyedszámú állomány jött létre az elmúlt évek során.

11 táblázat: A mezei nyúl állománysürúségének változása a Szilasok mintaterületen Table 11: Changes in Brown Hare population density on the Szilasok Sample Site

\begin{tabular}{|c|c|c|c|c|c|c|c|}
\hline Imérés időpor & 1 & $e^{2}$ & 3.na & $1+0$ & Mintaterule & Ȧllománysúrúség & \\
\hline & 1. day & 2. day & 3. day & Average & Sample site & Population density & $s^{2}$ \\
\hline $\begin{array}{l}\text { Atlag nap/ } \\
\text { Average day }\end{array}$ & $\begin{array}{l}\mathbf{d b} / \\
\text { ind. }\end{array}$ & $\begin{array}{l}\mathbf{d b} / \\
\text { ind. }\end{array}$ & $\begin{array}{l}\mathbf{d b} / \\
\text { ind. }\end{array}$ & $\begin{array}{l}\mathbf{d b} / \\
\text { ind. }\end{array}$ & $\begin{array}{c}\text { ha/ } \\
\text { ha }\end{array}$ & $\begin{array}{c}\mathbf{d b} / \mathbf{h a} \\
\text { ind./ha }\end{array}$ & \\
\hline 2008.10 .03 & 89,00 & 102,00 & 80,00 & 90,33 & 134,70 & 0,6706 & 0,01 \\
\hline 2009.04.01 & 51,00 & 36,00 & 50,00 & 45,67 & 142,45 & 0,3206 & 0,00 \\
\hline 2009.11.29 & 40,00 & 39,00 & 51,00 & 83,33 & 140,89 & 0,5915 & 0,00 \\
\hline 2010.03 .30 & 54,00 & 54,00 & 46,00 & 51,33 & 143,29 & 0,3582 & 0,00 \\
\hline 2010.10.07 & 32,00 & 24,00 & 18,00 & 24,67 & 134,06 & 0,1840 & 0,00 \\
\hline 2011.04 .05 & 52,00 & 25,00 & 33,00 & 36,67 & 138,76 & 0,2642 & 0,01 \\
\hline 2011.10.18 & 65,00 & 36,00 & 40,00 & 47,00 & 142,45 & 0,3299 & 0,01 \\
\hline 2012.03 .13 & 50,00 & 67,00 & 54,00 & 57,00 & 146,09 & 0,3902 & 0,00 \\
\hline 2012.10 .25 & 79,00 & 96,00 & 89,00 & 88,00 & 139,33 & 0,6316 & 0,00 \\
\hline
\end{tabular}

A Dévaványai Vadásztársaság a terület vadászati hasznosítója. Az öszi számlálások mindig megelőzték a vadászati szezon kezdetét. Ez alól kivételt a 2009-es esztendő jelentett, 
mikor annyira kedvezőtlenek voltak a terepviszonyok, hogy az éjszakai felméréseket csak november utolsó napjaiban tudtuk végrehajtani, de ekkor már megkezdődött a vadászati szezon. A becslések előtt elejtett egyedszámot ( $40 \mathrm{db}$ ) a 2009 őszi adatokba beépítettem, így ebben az esetben korrekció történt (12. táblázat).

A bejárási útvonal szinte végig árokparttal, néhol fasorral kísért földúton halad, ezért a szegélyhatás a méréseknél különböző mértékben lépett fel. Ennek következményét láthatjuk a 2010 ősz - 2011 tavasz és a 2011 ősz - 2012 tavasz adatainak összevetésénél, ahol mind a két esetben tavasszal nagyobb állománysürüséget tapasztaltunk.

Itt is jól nyomon követhetőek a 2010-es esztendő belvizes, hüvös és csapadékos időjárásának katasztrofális következményei. 2012-re heverte ki a mezeinyúl-állomány az akkori állománycsökkenést (18. ábra).

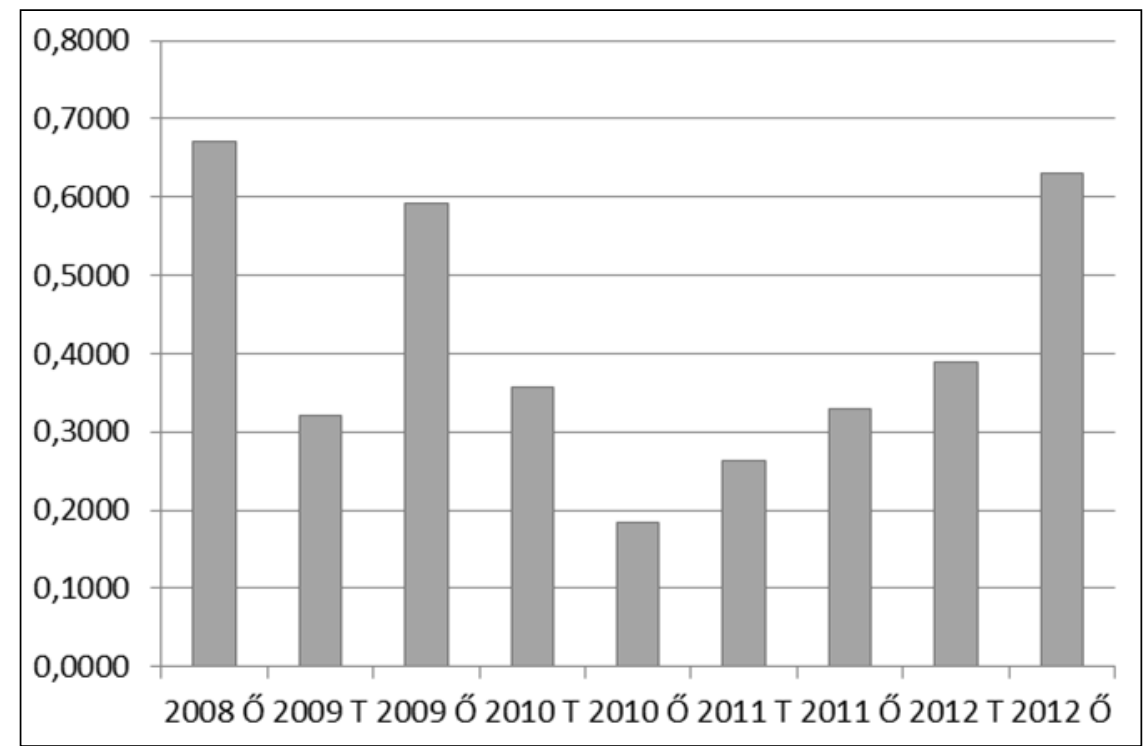

18. ábra: A mezei nyúl állománysűrüségének (db/ha) változása a Szilasok mintaterületen Figure 18: Changes in Brown Hare population density on the Szilasok Sample Site

\section{A három kijelölt mintaterület összehasonlitása}

Az állománysürüség vizsgálata során (a 2009 késő őszi-téli felmérések figyelmen kívül hagyásával) a legalacsonyabb értékek 2010 őszén a Szilasoknál $0,18 \mathrm{db} / \mathrm{ha}$-al és Réhelynél 0,28 db/ha-al adódnak. Mindkét adat a 2010-es csapadékos, belvizes esztendő kedvezötlen hatásainak köszönheti szélsőségesen alacsony értékét.

12. táblázat: A mezei nyúl állománysürüségének (db/ha) változása a mintaterületeken Table 12: Changes in Brown Hare population density (ind./ha) on the sample sites

\begin{tabular}{|c|c|c|c|c|c|c|c|c|c|}
\hline & 2008 Ö & $2009 T$ & 2009 Ö & $2010 \mathrm{~T}$ & 2010 Ö & $2011 \mathrm{~T}$ & 2011 Ö & $2012 \mathrm{~T}$ & 2012 Ö \\
\hline TVMT & 3,7578 & 2,9478 & 2,5069 & 3,0286 & 1,2577 & 1,6408 & 1,8388 & 1,0263 & 0,9889 \\
\hline Réhely & 0,7671 & 0,4614 & 0,1520 & 0,0000 & 0,2355 & 0,1983 & 0,3988 & 0,3186 & 0,2171 \\
\hline Szilasok & 0,6706 & 0,3206 & 0,5915 & 0,3582 & 0,1840 & 0,2642 & 0,3299 & 0,3902 & 0,6316 \\
\hline
\end{tabular}

A legnagyobb állománysürüségi mutatókat 2008 öszén becsültük, mikor a Túzokvédelmi belső mintaterületen nagyon magas, 3,76 db/ha értéket rögzítettünk (12. táblázat). 


\subsection{VADÁSZATI BEAVATKOZÁSOK A MINTATERÜLETEKEN}

A Réhelyi oldal és a Túzokvédelmi Mintaterület vadászati hasznosítója a KörösMaros Nemzeti Park Igazgatóság, a kijelölt vadászterület természetvédelmi célú, különleges rendeltetésú. Kialakításának legfontosabb célja a pusztai élőhelyek és fajkészletük fokozott védelme, a dévaványai túzokpopuláció hosszútávú megőrzése.

A Szilasokon a vadászati hasznosító a Dévaványai Vadásztársaság, aki évtizedek óta szakszerü vadgazdálkodást folytat az érintett területen.

\section{Réhely mintaterület}

A vizsgált időszakban mezei nyúl vadászat vagy élőnyúlbefogás a területen nem történt.

\section{Szilasok mintaterület}

A Szilasokon a Dévaványai Vadásztársaság az évtizedes gyakorlatának megfelelően végezte vadgazdálkodási tevékenységét a vizsgált időszakban is (13. táblázat). A 2004-ben indult Túzok Life program keretében a Körös-Maros Nemzeti Park Igazgatóság példamutató élőhelyfejlesztést valósított meg, ahol a pozitív hatásoknak az egyik haszonélvezője a mezeinyúl-állomány volt. A vadászati hasznosítás formája kivétel nélkül a társas vadászat volt, élőnyúlbefogással ezen a területen nem foglalkoztak.

13. táblázat: A vadászati hasznosítás mértéke a Szilasokon Table 13: Hunting bag on the Szilasok area

\begin{tabular}{ccc}
\hline & $\begin{array}{c}\text { Dévaványai VT teljes vadászterülete (db)/ } \\
\text { Dévaványa HA hunting area (ind.) }\end{array}$ & $\begin{array}{c}\text { Szilasok mintaterület (db)/ } \\
\text { Szilasok Sample Site (ind.) }\end{array}$ \\
\hline $\mathbf{2 0 0 8 - 2 0 0 9}$ & 522 & 40 \\
$\mathbf{2 0 0 9 - 2 0 1 0}$ & 628 & 60 \\
$\mathbf{2 0 1 0 - 2 0 1 1}$ & 175 & 8 \\
$\mathbf{2 0 1 1 - 2 0 1 2}$ & 811 & 76 \\
\hline
\end{tabular}

Az éjszakai reflektoros mezei nyúl felvételezések mindig az őszi vadászati szezon beindulása előtt történtek, mely alól a kedvezőtlen időjárási körülményeknek köszönhetően a 2009-es esztendő az egyetlen kivétel. Ekkor a vadászati hasznosítás mértékét beszámítottam a terület őszi állománysürüségébe.

\section{Túzokvédelmi Mintaterület}

A mezeinyúl-állomány adatgyüjtése során, mintavételi jelleggel két alkalommal került sor hajtóvadászatra a Túzokvédelmi Mintaterületen. 2008 őszén 58 darab, 2009 őszén 113 darab mezei nyúl került terítékre. A zárt, magasabb állománysürüségű Túzokvédelmi Mintaterületen végrehajtott mintavétel jellegű vadászatok alkalmával (171 egyed) magasabb volt a hím nyulak $(59,06 \%)$ aránya, mint nőstényeké $(40,94 \%)$. 


\subsection{AZ ÉLÖHELYTÍPUSOK MEGOSZLÁSA, AZ ÉLÖHELYKÍNÁLAT VÁLTOZÁSA A MINTATERÜLETEKEN}

Az élőhelytípusok részletes felmérését és elemzését 3 éven keresztül, 2010 és 2012 között végeztük el, évente kétszer, tavasszal és ősszel, a mezeinyúl-számlálásokkal egybeeső időpontban.

A Szilasok és a Túzokvédelmi belső mintaterület esetében a viszonylag állandó, többéves mezőgazdasági kultúrák, úgymint a gyep, a lucerna és a zöldugar $60 \%$ körül alakul, addig a Réhelyi mintaterület esetében mintegy 45\%-ot tesz ki a területi arányuk. Ezzel párhuzamosan az első két mintaterületnél a kedvezőbb viszonyokat segíti a változatos kultúrákat befogadó kisparcellák jelenléte, míg a Réhely mintaterület esetében a nagyüzemi táblakiosztás érvényesül.

Különösen fontos a mezei nyulak számára, hogy a növényzet nélküli területek, a szántások vagy más néven feketeugarok, minél kisebb területi hányadot foglaljanak el az életterükből és az év során minél rövidebb ideig legyenek fedetlenek. A növényzet mint pótolhatatlan táplálékforrás elengedhetetlen, de a rejtőzködést szolgáló pihenő- és búvóhelyek számára is kulcsfontosságú.

Az őszi vetések részleges megsemmisülésének köszönhetően, illetve az újravetések miatt a tavaszi felmérések pontosabb képet adnak, ha a fedetlen területekre vagyunk kíváncsiak. 2010 tavaszán a rendkívüli belvíz miatt Réhelyben a felméréseket nem lehetett elvégezni, ezért a 2011. április 4-6. közötti és a 2012. március 12-14. közötti felvételezéseket dolgoztam fel részletesen mind a három mintaterület esetében.

Az egyes vizsgált időszakok között az őszi és a tavaszi felméréseknél vagy a viszonylag állandó gyepnél kisebb különbségeket fedezhetünk fel. Ezeknek az eltéréseknek az oka egyrészt, hogy a csapadékhiány miatt gyengén kelő őszi káposztarepcét, esetleg őszi gabonát tavasszal újra kellett vetni, másrészt a mezőgazdasági munkák időbeli elmaradása vagy a növényzet magasságának következtében az észlelési távolságok eltérnek az egyes esztendőkben.

\section{Túzokvédelmi belsö mintaterület}

A lezárt Túzokvédelmi Mintaterület mintegy 15\%-át teszi ki az éjszakai reflektoros nyúlszámlálással érintett Túzokvédelmi belső mintaterület, amely fó mutatóit tekintve leképezi a zárt terület élőhelyi arányait. Minthogy a zárt Mintaterület kialakítása, a területkiválasztás, illetve a lekerítés eleve a túzokok ökológiai igényeinek megfelelöen történt, így kedvező helyzet alakult ki a mezei nyulak számára is.

A felmért mintaterület közel negyede ősgyep, illetve 20 méter széles táblák közötti gyepsáv. A lucerna - ugar - őszi káposzta vetésforgó a terület felét fedi le, 1-4 hektáros táblanagysággal. Az őszi búza területe 20-24\%-ot tesz ki (14. táblázat). 


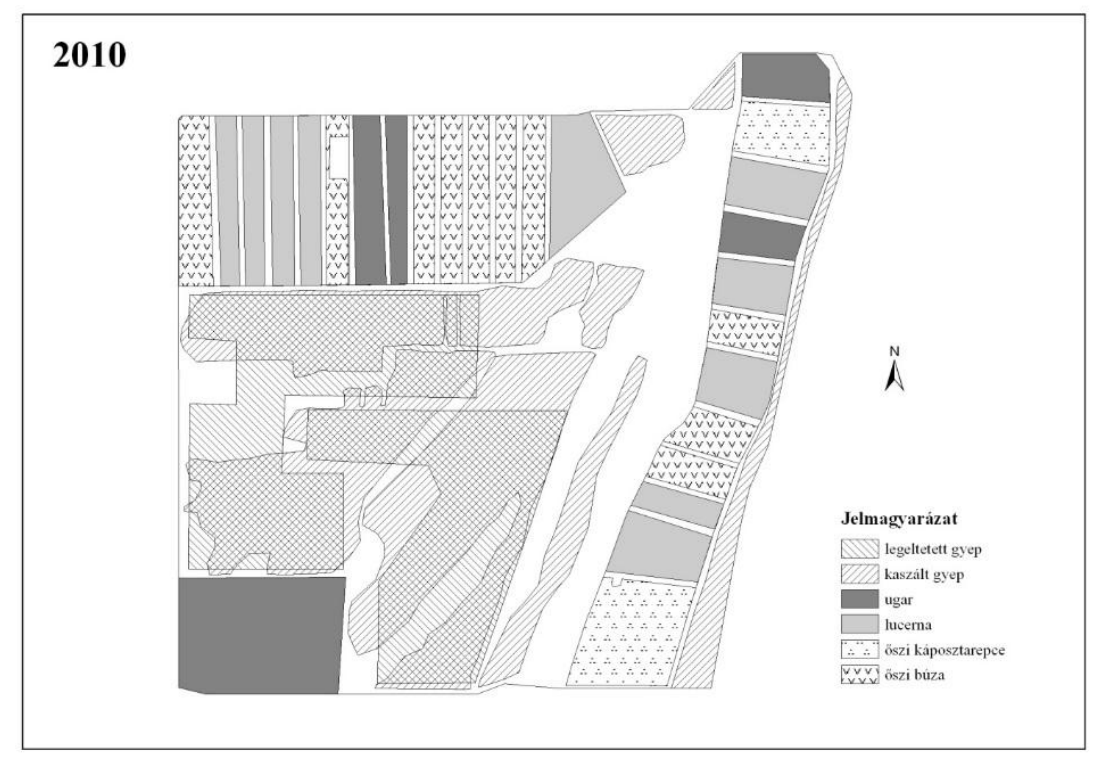

19. ábra: A Túzokvédelmi Mintaterület élőhelykezelése 2009/2010-ben

Figure 19: Habitat management on the Great Bustard Conservation Site in 2009/2010-ben

14. táblázat: A Túzokvédelmi belső mintaterület élőhelytípusainak megoszlása (2010-2012)

Table 14: Distribution of habitat types on the Great Bustard Interior Sample Site (2010-2012)

\begin{tabular}{|c|c|c|c|c|c|c|c|c|c|c|c|c|c|}
\hline & \multicolumn{2}{|c|}{ Gyep } & \multicolumn{2}{|c|}{ Ugar } & \multicolumn{2}{|c|}{ Lucerna } & \multicolumn{2}{|c|}{ Repce } & \multicolumn{2}{|c|}{ Öszi búza } & \multicolumn{2}{|c|}{ Fek. ugar } & \multirow[t]{2}{*}{$\sum$} \\
\hline & ha & $\%$ & ha & $\%$ & ha & $\%$ & ha & $\%$ & ha & $\%$ & ha & $\%$ & \\
\hline 2010.03.30 & 15,54 & $26 \%$ & 6,48 & $11 \%$ & 16,84 & $28 \%$ & 7,77 & $13 \%$ & 14,25 & $23 \%$ & 0,00 & $0 \%$ & 60,87 \\
\hline 2010.10 .07 & 12,30 & $21 \%$ & 9,52 & $16 \%$ & 17,68 & $30 \%$ & 8,16 & $14 \%$ & 0,00 & $0 \%$ & 12,24 & $20 \%$ & 59,90 \\
\hline 2011.04 .05 & 15,54 & $28 \%$ & 7,52 & $13 \%$ & 15,29 & $27 \%$ & 6,23 & $11 \%$ & 11,28 & $20 \%$ & 0,00 & $0 \%$ & 55,87 \\
\hline 2011 & 14,76 & $24 \%$ & 13,60 & $22 \%$ & 13,60 & $22 \%$ & 5,44 & $9 \%$ & 10,88 & $17 \%$ & 4,08 & $7 \%$ & 62,36 \\
\hline 2012.03 .13 & 14,76 & $24 \%$ & 12,24 & $20 \%$ & 9,52 & $15 \%$ & 5,44 & $9 \%$ & 14,96 & $24 \%$ & 5,44 & $9 \%$ & 62,36 \\
\hline 2012.10 .25 & 14,76 & $24 \%$ & 13,60 & $22 \%$ & 13,60 & $22 \%$ & 5,44 & $9 \%$ & 10,88 & $17 \%$ & 4,08 & $7 \%$ & 62,36 \\
\hline
\end{tabular}

A Túzokvédelmi Mintaterület elsődleges rendeltetése a túzokok életfeltételeinek biztosítása, ezért a vetésforgó előre tervezett, ahol a termesztett, illetve fenntartott mezőgazdasági kultúrák a legkedvezőbb növényfajokból állnak. A tervezésnek köszönhetően az arányok állandónak tekinthetők, a téli időszakban a fedetlen szántók területi kiterjedése minimális.

A Túzokvédelmi Mintaterületen a szántóföldi táblákat (T9, T6, T5) a menedéket nyújtó, egyben táplálékbázist biztosító gyepsávok választják szét, amelyek az élőhelyek mozaikosságát is növelik. A gyepek kezelése késői kaszálással és nyárvégi-őszi legeltetéssel történik, amely tovább növeli a terület sokszínüségét (20. ábra). 


\section{Réhely mintaterület (kontrollterület)}

A mintaterület fö jellemzője, hogy míg a gyep, a lucerna és a zöldugar nem éri el a vizsgált terület felét, addig a szántókon a nagytáblás müvelés, az intenzív kultúrák fenntartása általánosnak tekinthető. A termőhelyi adottságok nemcsak lehetővé teszik, de kedvezőek a napraforgó termesztésére. Ennek köszönhetően a téli időszakokban a feketeugar aránya kifejezetten magas, a vizsgált időszakban 23\%-ot és $40 \%$-ot mutatott (15. táblázat). Ez a kedvezőtlen helyzet párosul a nagytáblás müvelés másik negatívumával, amikor aratáskor, szántáskor vagy tárcsázáskor akár több száz hektáron is egy időben semmisül meg az értékes élőhelyegyüttes.

15. táblázat: A Réhely mintaterület élőhelytípusainak megoszlása (2010-2012) Table 15: Distribution of habitat types on the Réhely Sample Site (2010-2012)

\begin{tabular}{rcccccccccccccc}
\hline & \multicolumn{3}{c}{ Gyep } & \multicolumn{2}{c}{ Ugar } & \multicolumn{2}{c}{ Lucerna } & \multicolumn{2}{c}{ Repce } & \multicolumn{2}{c}{ Öszi búza } & Fek. ugar & $\Sigma$ \\
\cline { 2 - 15 } & ha & $\%$ & \multicolumn{1}{c}{ ha } & $\%$ & ha & $\%$ & ha & $\%$ & ha & $\%$ & ha & $\%$ & \\
\hline 2010.03 .30 & - & - & - & - & - & - & - & - & - & - & - & - & - \\
2010.10 .07 & 22,14 & $18 \%$ & 4,67 & $4 \%$ & 21,77 & $18 \%$ & 15,99 & $13 \%$ & 0,00 & $0 \%$ & 55,76 & $46 \%$ & 120,34 \\
2011.04 .05 & 23,31 & $17 \%$ & 9,07 & $7 \%$ & 33,67 & $25 \%$ & 16,84 & $12 \%$ & 22,02 & $16 \%$ & 31,28 & $23 \%$ & 136,18 \\
2011.10 .18 & 19,31 & $15 \%$ & 9,84 & $7 \%$ & 17,22 & $13 \%$ & 4,92 & $4 \%$ & 0,00 & $0 \%$ & 81,60 & $61 \%$ & 132,89 \\
2012.03 .13 & 23,31 & $17 \%$ & 11,66 & $8 \%$ & 23,31 & $17 \%$ & 1,36 & $1 \%$ & 24,48 & $17 \%$ & 57,12 & $40 \%$ & 141,24 \\
2012.10 .25 & 19,31 & $15 \%$ & 9,84 & $7 \%$ & 16,11 & $12 \%$ & 2,46 & $2 \%$ & 27,20 & $21 \%$ & 57,12 & $43 \%$ & 132,04 \\
\hline
\end{tabular}

Az őszi búza mintegy 17\%-os állandó térfoglalással van jelen és kedvező időjárás esetén az őszi káposztarepce termesztése is jelentős lehet. Ennek a növénynek a túzokok téli táplálékforrásaként van kiemelt jelentősége, ezért a támogatásuk Dévaványa térségében különösen fontos feladat.

\section{Szilasok mintaterület (kontrollterület)}

A mintaterület közel 30\%-át természetszerü ösgyep borítja, melynek elhelyezkedése egybefüggő. A szintén állandó növénytakarót biztosító lucerna és zöldugar, amely mindenféle szempontból fontos a mezeinyúl-állomány számára, szintén közel 30\%-ot tesz ki, kisebb és nagyobb parcellákban is elöfordul (16. táblázat). A tavaszi szántások $12 \%$ és 23\% közötti értéket mutatnak, ahol napraforgót, kukoricát és cirkot is termesztettek.

16. táblázat: A Szilasok mintaterület élőhelytípusainak megoszlása (2010-2012) Table 16: Distribution of habitat types on the Szilasok Sample Site (2010-2012)

\begin{tabular}{rccccccccccccc}
\hline & \multicolumn{2}{c}{ Gyep } & \multicolumn{2}{c}{ Ugar } & \multicolumn{2}{c}{ Lucerna } & \multicolumn{3}{c}{ Repce } & \multicolumn{3}{c}{ Öszi búza } & \multicolumn{2}{c}{ Fek. ugar } & $\Sigma$ \\
\cline { 2 - 14 } & ha & $\%$ & ha & \multicolumn{1}{c}{$\%$} & ha & $\%$ & ha & $\%$ & ha & $\%$ & ha & $\%$ & \\
\hline 2010.03 .30 & 42,74 & $30 \%$ & 6,48 & $5 \%$ & 40,15 & $28 \%$ & 0,00 & $0 \%$ & 36,26 & $25 \%$ & 17,68 & $12 \%$ & 143,30 \\
2010.10 .07 & 40,59 & $30 \%$ & 12,30 & $9 \%$ & 34,07 & $25 \%$ & 8,61 & $6 \%$ & 0,00 & $0 \%$ & 38,49 & $29 \%$ & 134,06 \\
2011.04 .05 & 37,56 & $27 \%$ & 16,84 & $12 \%$ & 33,67 & $24 \%$ & 7,77 & $6 \%$ & 11,66 & $8 \%$ & 31,28 & $23 \%$ & 138,77 \\
2011.10 .18 & 40,59 & $28 \%$ & 11,07 & $8 \%$ & 15,99 & $11 \%$ & 0,00 & $0 \%$ & 0,00 & $0 \%$ & 74,80 & $53 \%$ & 142,45 \\
2012.03 .13 & 44,03 & $30 \%$ & 11,66 & $8 \%$ & 14,25 & $10 \%$ & 0,00 & $0 \%$ & 58,48 & $40 \%$ & 17,68 & $12 \%$ & 146,09 \\
2012.10 .25 & 40,59 & $29 \%$ & 12,30 & $9 \%$ & 15,99 & $11 \%$ & 28,29 & $20 \%$ & 32,64 & $23 \%$ & 9,52 & $7 \%$ & 139,33 \\
\hline
\end{tabular}


Bár a Szilasok mintaterület parcellakiosztását és a termelt mezőgazdasági növények döntő többségét a túzokvédelem célrendszere határozza meg, azonban a mezei nyulak számára is rendkívül kedvező. A fedetlen szántások aránya kicsi és elhelyezkedésük kedvező, így a mezei nyulak számára mindig rendelkezésre áll megfelelő élőhelytípus, ezért az életterükben ritkán alakul ki ökológiai krízishelyzet.

\section{A mintaterületek élőhelytípusainak összehasonlitása a tavaszi időszakban}

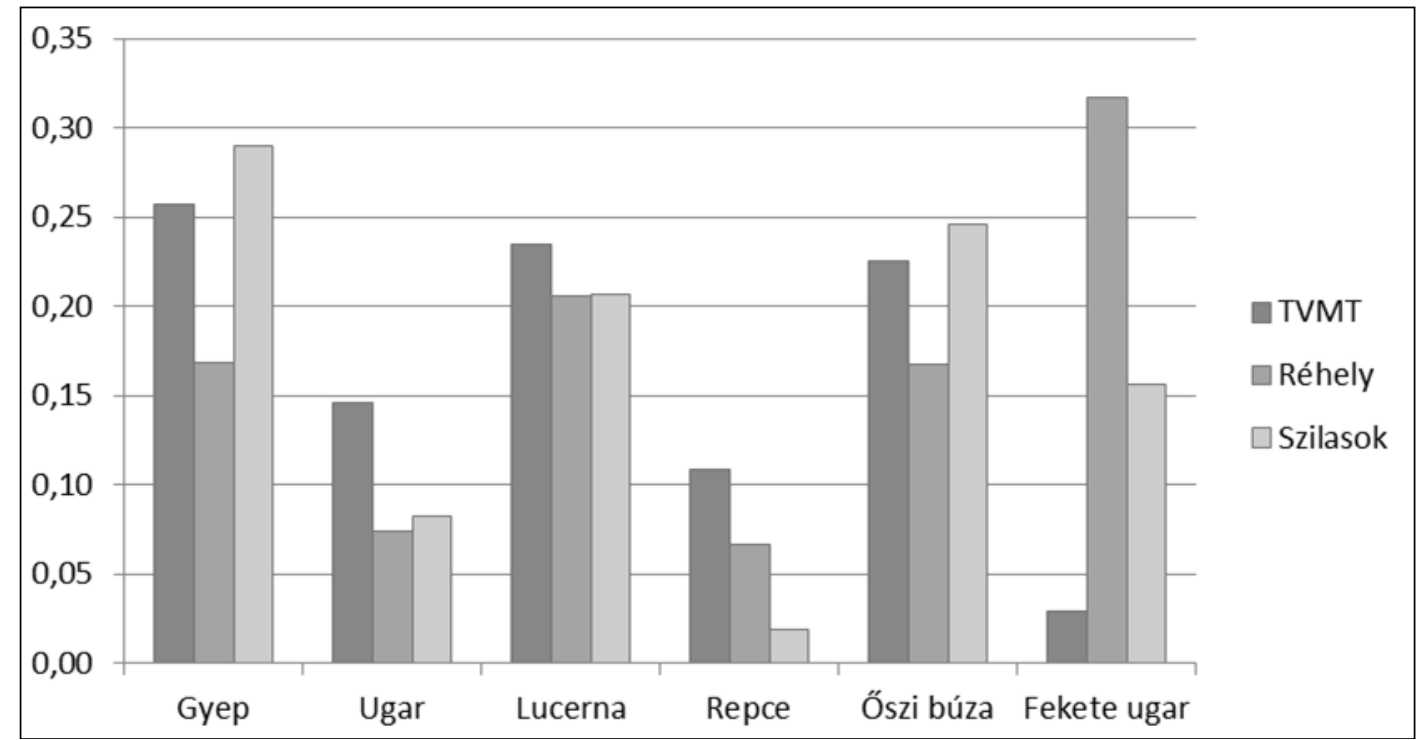

20. ábra: A mintaterületek élőhelytípusainak megoszlása (2011-2012 tavasz)

Figure 20: Distribution of habitat types os sample sites (2010-2012 spring)

A természetes gyepek aránya a Szilasok (29\%) és a Túzokvédelmi belső mintaterület (26\%) esetében közel azonos, míg a Réhely mintaterületnél jóval kisebb (17\%). Mindhárom mintaterület esetében a lucerna és az őszi búza területfoglalása közel azonos, a lucernánál $20 \%$ és $23 \%$, az őszi búzánál $17 \%$ és $24 \%$ közé tehető az érték. A zöldugar aránya a Túzokvédelmi belső mintaterületnél a legmagasabb, közel 15\%. A növényborítás nélküli feketeugar mutatja a legeltérőbb képet a tavaszi időszakban. A speciális túzokvédelmi kezelésnek köszönhetően a belső mintaterületnél alig éri el a 3\%-ot. A két külső kontrollterületnél 16\% (Szilasok), illetve 32\% (Réhely) az aránya, amely a tavaszi vetésü növényeknek, a napraforgónak és a kukoricának a vetésterületével egyezik meg. A mezeinyúl-állomány szempontjából ez számít a legkedvezőtlenebb élőhelynek.

\subsection{AZ ÉLÖHELYHASZNÁLAT VÁLTOZÁSA A MINTATERÜLETEKEN}

\section{Túzokvédelmi belsö mintaterület}

A Túzokvédelmi belső mintaterület speciális kisparcellás felosztása a mezei nyulak számára az egyes élöhelytípusok között sokkal könnyebb átmozgást tesz lehetővé, ezért az eredmények ebben az esetben kissé árnyaltabb képet mutatnak. Itt télen minden terület valamilyen növényzettel fedett, ezért téli időszakban szántóval csak abban az esetben találkozhatunk, ha a szárazság miatt eredménytelen az őszi repcevetés vagy a talajállapot, illetve az esetleges belvizek nem teszik lehetővé a gabona októberi-novemberi vetését. 
Az őszi időszakban a lucernán (38\%) és a repcén (24\%) található meg a nyulak több mint fele, ilyenkor a kaszált gyepek (15\%) és a zöldugarok (12\%) szerepe jóval kisebb, míg a friss gabonavetések, szántások jelentősége elhanyagolható (17. táblázat).

Az alacsony növényzettel bíró kaszált gyepek jelentősége tavaszra a Túzokvédelmi Mintaterületen megnő, az előfordulások mértéke eléri a 25\%-ot. A tavaszra megerősödött őszi búza ebben az esetben is $28 \%$-kal a legfontosabb élöhelynek számít, a lucernások szintén kedveltek (24\%) és a repceföldeket sem kerülik a táplálkozó nyulak (15\%).

17. táblázat: Az élőhelyhasználat változása a Túzokvédelmi belső mintaterületen (2010-2012)

Table 17: Changes in habitat use on the Great Bustard Interior Sample Site (2010-2012)

\begin{tabular}{lrrrrcc}
\hline & $\begin{array}{c}\text { Gyep } \\
(\%)\end{array}$ & \multicolumn{1}{c}{$\begin{array}{c}\text { Ugar } \\
(\%)\end{array}$} & $\begin{array}{c}\text { Lucerna } \\
(\%)\end{array}$ & $\begin{array}{c}\text { Repce } \\
(\%)\end{array}$ & $\begin{array}{c}\text { Öszi búza } \\
(\%)\end{array}$ & $\begin{array}{c}\text { Feketeugar } \\
(\%)\end{array}$ \\
\hline 2010.03 .30 & $14,58 \%$ & $9,62 \%$ & $26,53 \%$ & $24,49 \%$ & $24,78 \%$ & $0 \%$ \\
2010.10 .07 & $9,73 \%$ & $12,83 \%$ & $50,44 \%$ & $20,8 \%$ & $0 \%$ & $6,19 \%$ \\
2011.04 .05 & $18,18 \%$ & $11,64 \%$ & $40,36 \%$ & $7,27 \%$ & $22,55 \%$ & $0 \%$ \\
2011.10 .18 & $9,3 \%$ & $7,56 \%$ & $52,33 \%$ & $25,87 \%$ & $0, \%$ & $4,94 \%$ \\
2012.03 .13 & $41,15 \%$ & $1,04 \%$ & $4,17 \%$ & $14,58 \%$ & $38,02 \%$ & $1,04 \%$ \\
2012.10 .25 & $25,95 \%$ & $16,22 \%$ & $10,81 \%$ & $25,95 \%$ & $13,51 \%$ & $7,57 \%$ \\
\hline Tavasz & $24,63 \%$ & $7,43 \%$ & $23,69 \%$ & $15,45 \%$ & $28,45 \%$ & $0,35 \%$ \\
\hline Ösz & $14,99 \%$ & $12,2 \%$ & $37,86 \%$ & $24,2 \%$ & $4,5 \%$ & $6,23 \%$ \\
\hline
\end{tabular}

A három mintaterület adatait áttekintve megállapítható, hogy az őszi-tavaszi időszakot együttesen figyelembe véve, a legkedveltebb élőhelynek a lucernások $(30 \%, 25 \%)$ számítanak. A legjelentősebb koncentrációt 35\%-kal az öszi búza tavaszi állományai mutatták. Összel még kiemelt szerepe van a jól sikerült őszi káposztarepce vetésnek, ahol ebben az időszakban a mezei nyulak 23\%-át regisztráltuk. A gyepeken táplálkozó egyedek száma mind ősszel, mind tavasszal viszonylag állandó, mértéke $15 \%$-ot, illetve $14 \%$-ot tett ki.

\section{Réhely mintaterület (kontrollterület)}

A mintaterület esetében általánosságban megállapítható, hogy Atyaszegen a gyepeken bár előfordul a mezei nyúl, de csak nagyon kis egyedszámmal, állománya évszaktól függetlenül állandó egyedszámú.

Összel az állomány a repceföldekre és a lucernásokra koncentrálódik, ekkor a fö táplálékforrást is ezek a mezőgazdasági kultúrák biztosítják, de rendszeresen megjelenik az ugaron, a frissen vetett őszi gabonán és a szántott területeken is (18. táblázat).

A tavaszi állományfelmérésekkor a lucerna jelentősége nem változott, ebben az időszakban is a mezei nyulak mintegy $30 \%$-a ezt az élőhelytípust választotta. A felnövekvő repcét azonban a nyulak részben elhagyták és a már megerősödött öszi gabonavetésben jelentek meg a legnagyobb egyedszámban, arányuk 38\%-ot ért el. 
18. táblázat: Az élőhelyhasználat változása a Réhely mintaterületen (2010-2012) Table 18: Changes in habitat use on the Réhely Sample Site (2010-2012)

\begin{tabular}{lcrcccc}
\hline & $\begin{array}{c}\text { Gyep } \\
(\%)\end{array}$ & \multicolumn{1}{c}{$\begin{array}{c}\text { Ugar } \\
(\%)\end{array}$} & $\begin{array}{c}\text { Lucerna } \\
(\%)\end{array}$ & $\begin{array}{c}\text { Repce } \\
(\%)\end{array}$ & $\begin{array}{c}\text { Őszi búza } \\
(\%)\end{array}$ & $\begin{array}{c}\text { Feketeugar } \\
(\%)\end{array}$ \\
\hline 2010.03 .30 & - & - & - & - & - & - \\
2010.10 .07 & $4,71 \%$ & $2,35 \%$ & $11,76 \%$ & $60,00 \%$ & $0 \%$ & $21,18 \%$ \\
2011.04 .05 & $1,23 \%$ & $4,94 \%$ & $34,57 \%$ & $8,64 \%$ & $34,57 \%$ & $16,05 \%$ \\
2011.10 .18 & $6,29 \%$ & $27,04 \%$ & $50,94 \%$ & $5,66 \%$ & $0 \%$ & $10,06 \%$ \\
2012.03 .13 & $2,96 \%$ & $11,11 \%$ & $25,93 \%$ & $2,96 \%$ & $41,48 \%$ & $15,56 \%$ \\
2012.10 .25 & $16,28 \%$ & $8,14 \%$ & $13,95 \%$ & $8,14 \%$ & $37,21 \%$ & $16,28 \%$ \\
\hline Tavasz & $2,10 \%$ & $8,02 \%$ & $30,25 \%$ & $5,80 \%$ & $38,02 \%$ & $15,80 \%$ \\
\hline Ösz & $9,09 \%$ & $12,51 \%$ & $25,55 \%$ & $24,60 \%$ & $12,40 \%$ & $15,84 \%$ \\
\hline
\end{tabular}

\section{Szilasok mintaterület (kontrollterület)}

A Szilasok védett legelő területe, illetve a kaszálóként használt hátasabb részei állandó mezeinyúl-állománynak ad otthont. Ezt az élőhelyet csak rendkívüli szárazság esetén hagyják el az állatok.

Összel itt is a lucerna (26\%) és az őszi káposztarepce a meghatározó (20\%), az ősgyeppel és a vetett gyepekkel (22\%) együtt a mezei nyulak kétharmada ezeket az élőhelyeket választja (19. táblázat).

A lucerna tavasszal is megtartja jelentőségét (23\%), azonban ekkor már a nyulak számára a legkedveltebb mezőgazdasági kultúrának a jó növekedést mutató őszi búza (40\%) számít.

19. táblázat: Az élőhelyhasználat változása a Szilasok mintaterületen (2010-2012)

Table 19: Changes in habitat use on the Szilasok Sample Site (2010-2012)

\begin{tabular}{lcccccc}
\hline & $\begin{array}{c}\text { Gyep } \\
(\%)\end{array}$ & $\begin{array}{c}\text { Ugar } \\
(\%)\end{array}$ & $\begin{array}{c}\text { Lucerna } \\
(\%)\end{array}$ & $\begin{array}{c}\text { Repce } \\
(\%)\end{array}$ & $\begin{array}{c}\text { Öszi búza } \\
(\%)\end{array}$ & $\begin{array}{c}\text { Feketeugar } \\
(\%)\end{array}$ \\
\hline 2010.03 .30 & $22,08 \%$ & $5,19 \%$ & $33,12 \%$ & $0 \%$ & $21,43 \%$ & $18,18 \%$ \\
2010.10 .07 & $18,92 \%$ & $5,41 \%$ & $25,68 \%$ & $28,38 \%$ & $0 \%$ & $21,62 \%$ \\
2011.04 .05 & $14,55 \%$ & $9,09 \%$ & $34,55 \%$ & $2,73 \%$ & $10,00 \%$ & $29,09 \%$ \\
2011.10 .18 & $31,21 \%$ & $13,48 \%$ & $39,01 \%$ & $0 \%$ & $0 \%$ & $16,31 \%$ \\
2012.03 .13 & $9,36 \%$ & $0,58 \%$ & $0 \%$ & $0 \%$ & $87,72 \%$ & $2,34 \%$ \\
2012.10 .25 & $14,39 \%$ & $1,52 \%$ & $12,88 \%$ & $30,30 \%$ & $39,77 \%$ & $1,14 \%$ \\
\hline Tavasz & $15,33 \%$ & $4,96 \%$ & $22,55 \%$ & $0,91 \%$ & $39,72 \%$ & $16,54 \%$ \\
\hline Ösz & $21,51 \%$ & $6,80 \%$ & $25,85 \%$ & $19,56 \%$ & $13,26 \%$ & $13,02 \%$ \\
\hline
\end{tabular}

\subsection{AZ ÉLŐHELYVÁLASZTÁS VÁLTOZÁSA A MINTATERÜLETEKEN}

Az éjszakai reflektoros állománybecslések előfordulási adatait felhasználva elemeztem a mezei nyúl élőhelyválasztását a három (Túzokvédelmi belső mintaterület, Réhely, Szilasok) mintaterületen. A részletes vizsgálathoz az Ivlev-indexet $\left(\mathrm{E}_{\mathrm{i}}\right)$ és a Jacobs-indexet $\left(\mathrm{D}_{\mathrm{i}}\right)$ számoltam ki észlelésenként és élőhelytípusonként. 


\section{Túzokvédelmi belsö mintaterület}

A Túzokvédelmi belső mintaterületen az őszi káposztarepce kimagasló értékeket $\left(E_{i=} 0,2594 ; D_{i}=0,6068\right)$ eredményezett, ezzel a leginkább kedvelt élőhelytípusnak számított a zárt területen. Ezt követte az őszi búza $\left(\mathrm{E}_{\mathrm{i}=0,0366 ;} \mathrm{D}_{\mathrm{i}}=0,0696\right)$ és a lucerna $\left(E_{\mathrm{i}=} 0,-0,0107 ; D_{\mathrm{i}}=0,0437\right)$, érdekes módon ezen a mintaterületen jóval elmaradt a kiszámított indexük. A gyep itt is alacsony értékeket $\left(E_{i=}-0,1599 ; D_{i}=-0,1786\right)$ hozott és a szántott területeken is csak alkalomszerüen, kis egyedszámmal lehetett a mezei nyulakat észlelni $\left(\mathrm{E}_{\mathrm{i}=}=\right.$ 0,$\left.3470 ; \mathrm{D}_{\mathrm{i}}=-0,3655\right)$ (20. táblázat, 21. táblázat).

20. táblázat: Az Ivlev-index $\left(\mathrm{E}_{\mathbf{i}}\right)$ változása a Túzokvédelmi belső mintaterületen (2010-2012)

Table 20: Changes of Ivlev's electivity index $\left(E_{i}\right)$ on the Great Bustard Interior Sample Site (2010-2012)

\begin{tabular}{ccccccc}
\hline & Gyep & Ugar & Lucerna & Repce & Őszi búza & Feketeugar \\
\hline 2010.03 .30 & $-0,27$ & $-0,05$ & $-0,02$ & 0,31 & 0,03 & - \\
2010.10 .07 & $-0,36$ & $-0,11$ & 0,26 & 0,21 & - & $-0,53$ \\
2011.04 .05 & $-0,21$ & $-0,07$ & 0,19 & $-0,21$ & 0,06 & - \\
2011.10 .18 & $-0,44$ & $-0,49$ & 0,41 & 0,50 & - & $-0,14$ \\
2012.03 .13 & 0,27 & $-0,90$ & $-0,57$ & 0,25 & 0,23 & $-0,79$ \\
2012.10 .25 & 0,05 & $-0,15$ & $-0,34$ & 0,50 & $-0,13$ & 0,07 \\
\hline
\end{tabular}

21. táblázat: A Jacobs-index $\left(D_{i}\right)$ változása a Túzokvédelmi belső mintaterületen (2010-2012)

Table 21: Changes of Jacob's index $\left(D_{i}\right)$ on the Great Bustard Interior Sample Site (2010-2012)

\begin{tabular}{ccccccc}
\hline & Gyep & Ugar & Lucerna & Repce & Öszi búza & Feketeugar \\
\hline 2010.03 .30 & $-0,34$ & $-0,06$ & $-0,03$ & 0,38 & 0,04 & - \\
2010.10 .07 & $-0,41$ & $-0,12$ & 0,42 & 0,25 & - & $-0,59$ \\
2011.04 .05 & $-0,27$ & $-0,08$ & 0,28 & $-0,23$ & 0,07 & - \\
2011.10 .18 & $-0,50$ & $-0,55$ & 0,59 & 0,57 & - & $-0,15$ \\
2012.03 .13 & 0,39 & $-0,92$ & $-0,61$ & 0,28 & 0,32 & $-0,80$ \\
2012.10 .25 & 0,06 & $-0,18$ & $-0,39$ & 0,57 & $-0,15$ & 0,08 \\
\hline
\end{tabular}

A Túzokvédelmi belső mintaterület esetében szintén elhagyták a mezei nyulak a száraz gyepeket 2011 öszén, azonban 2012 márciusában, a rendkívüli hófedettséget eredményező február után néhány héttel, jelentős volt a kaszálókon az egyedszámuk.

\section{Réhely mintaterület (kontrollterület)}

Az őszi káposztarepce mutatta a legmagasabb értéket mind a két mutató esetében $\left(E_{i=0,3613 ;} D_{i}=0,4001\right)$, ezt követte az őszi búza $\left(E_{i=0,2121 ;} D_{i}=0,2799\right)$, majd a lucerna

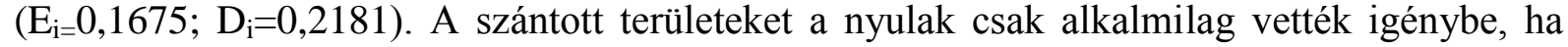
tehették kerülték ezeket a fedetlen élőhelyeket $\left(E_{i=}-0,4332 ; D_{i}=-0,5559\right)$. A gyepek megítéléséhez az indexek nem használhatók, mivel az atyaszegi gyep nagy, összefüggő tömböt alkot, ezért az egyedek átmozgása korlátozott (22. táblázat, 23. táblázat). 
22. táblázat: Az Ivlev-index ( $\left.E_{\mathbf{i}}\right)$ változása a Réhely mintaterületen (2010-2012)

Table 22: Changes of Ivlev's electivity index $\left(E_{i}\right)$ on the Réhely Sample Site (2010-2012)

\begin{tabular}{ccccccc}
\hline & Gyep & Ugar & Lucerna & Repce & Öszi búza & Feketeugar \\
\hline 2010.03 .30 & - & - & - & - & - & - \\
2010.10 .07 & $-0,59$ & $-0,25$ & $-0,21$ & 0,64 & - & $-0,37$ \\
2011.04 .05 & $-0,87$ & $-0,15$ & 0,17 & $-0,18$ & 0,36 & $-0,18$ \\
2011.10 .18 & $-0,40$ & 0,57 & 0,59 & 0,21 & - & $-0,72$ \\
2012.03 .13 & $-0,70$ & 0,15 & 0,22 & 0,51 & 0,41 & $-0,44$ \\
2012.10 .25 & 0,05 & 0,04 & 0,07 & 0,63 & 0,29 & $-0,45$ \\
\hline
\end{tabular}

23. táblázat: A Jacobs-index $\left(D_{i}\right)$ változása a Réhely mintaterületen (2010-2012)

Table 23: Changes of Jacob's index $\left(D_{i}\right)$ on the Réhely Sample Site (2010-2012)

\begin{tabular}{ccccccc}
\hline & Gyep & Ugar & Lucerna & Repce & Öszi búza & Feketeugar \\
\hline 2010.03 .30 & 0,00 & 0,00 & 0,00 & 0,00 & 0,00 & 0,00 \\
2010.10 .07 & $-0,64$ & $-0,25$ & $-0,25$ & 0,81 & - & $-0,53$ \\
2011.04 .05 & $-0,89$ & $-0,16$ & 0,23 & $-0,20$ & 0,47 & $-0,22$ \\
2011.10 .18 & $-0,43$ & 0,65 & 0,75 & 0,22 & - & $-0,87$ \\
2012.03 .13 & $-0,73$ & 0,16 & 0,28 & 0,52 & 0,54 & $-0,57$ \\
2012.10 .25 & 0,06 & 0,05 & 0,08 & 0,65 & 0,39 & $-0,59$ \\
\hline
\end{tabular}

Jól nyomon követhető, hogy a 2011. évi őszi rendkívüli szárazság időszakában a gyepekről elmozdultak a nyulak és a némi friss hajtást hozó ugarok szerepe pedig jelentősen felértékelődött. A 2012. februári havazás, ami 4 hetes folyamatos hóborítást eredményezett, szintén a mezei nyulak eltünését okozta a gyepekröl.

\section{Szilasok mintaterület (kontrollterület)}

A mintaterület esetében a két leginkább preferált élöhely szinte azonos értékkel az őszi búza $\left(E_{i=0} 0,1590 ; D_{i}=0,2959\right)$ és az öszi káposztarepce $\left(E_{i=}=0,1612 ; D_{i}=0,2026\right)$. Nem sokkal

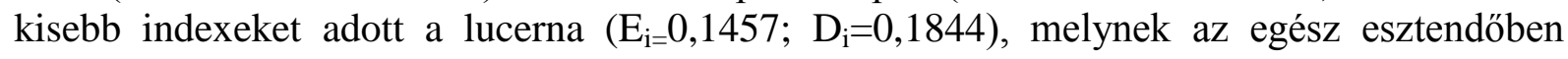
kiemelt szerep jut a térségben.

24. táblázat: Az Ivlev-index ( $\left.\mathbf{E}_{\mathrm{i}}\right)$ változása a Szilasok mintaterületen (2010-2012)

Table 24: Changes of Ivlev's electivity index $\left(E_{i}\right)$ on the Szilasok Sample Site (2010-2012)

\begin{tabular}{ccccccc}
\hline & Gyep & Ugar & Lucerna & Repce & Őszi búza & Feketeugar \\
\hline 2010.03 .30 & $-0,15$ & 0,07 & 0,08 & - & $-0,08$ & 0,19 \\
2010.10 .07 & $-0,23$ & $-0,26$ & 0,01 & 0,63 & - & $-0,14$ \\
2011.04 .05 & $-0,30$ & $-0,14$ & 0,17 & $-0,34$ & 0,09 & 0,13 \\
2011.10 .18 & 0,05 & 0,27 & 0,55 & - & - & $-0,53$ \\
2012.03 .13 & $-0,53$ & $-0,86$ & - & - & 0,37 & $-0,68$ \\
2012.10 .25 & $-0,34$ & $-0,71$ & 0,06 & 0,20 & 0,26 & $-0,71$ \\
\hline
\end{tabular}


25. táblázat: A Jacobs-index $\left(D_{\mathrm{i}}\right)$ változása a Szilasok mintaterületen (2010-2012)

Table 25: Changes of Jacob's index $\left(D_{i}\right)$ on the Szilasok Sample Site (2010-2012)

\begin{tabular}{lcccccc}
\hline & Gyep & Ugar & Lucerna & Repce & Őszi búza & Feketeugar \\
\hline 2010.03 .30 & $-0,20$ & 0,07 & 0,12 & - & $-0,11$ & 0,22 \\
2010.10 .07 & $-0,30$ & $-0,28$ & 0,01 & 0,70 & - & $-0,19$ \\
2011.04 .05 & $-0,37$ & $-0,16$ & 0,24 & $-0,36$ & 0,10 & 0,17 \\
2011.10 .18 & 0,06 & 0,30 & 0,67 & - & - & $-0,70$ \\
2012.03 .13 & $-0,61$ & $-0,87$ & - & - & 0,83 & $-0,70$ \\
2012.10 .25 & $-0,42$ & $-0,73$ & 0,07 & 0,26 & 0,37 & $-0,73$ \\
\hline
\end{tabular}

Ezen a mintaterületen is a szántott, tárcsázott táblák voltak a legkevésbé kedvelt területrészek $\left(\mathrm{E}_{\mathrm{i}=}-0,2899 ; \mathrm{D}_{\mathrm{i}}=-0,3209\right)$. A tavaszi értékek azért magasabbak, mert a párzáshoz kapcsolódó kergetőzések kimozdítják az egyébként táplálkozó egyedeket.

A Szilasok gyepterületén a mezei nyúl állománysürüsége alacsony, melynek következtében a terület egészére számolt indexek kifejezetten alacsony értéket mutatnak $\left(\mathrm{E}_{\mathrm{i}=}=-0,2501 ; \mathrm{D}_{\mathrm{i}}=-0,3068\right)$ (24. táblázat, 25. táblázat).

\section{4. ÉRTÉKELÉS}

A mezei nyúl leginkább a nyílt, változatos élőhelyeket kedveli, ahol előnyben részesíti az egymást időben és táplálékforrásban kiegészítő, kisparcellás szántóföldi kultúrákat. Kedvezően érinti az állományt ha a nyulak mozgáskörzetében ugarok, vetett gyepek, természetes gyepek, csenderesek vagy cserjeszinttel rendelkező fasorok is megtalálhatók, így a megfelelö pihenőhelyek is biztosítottak számára. A Szilasokon becsült állománysürüségi adatok ezt az élőhelyi igényt megerösítik, hiszen a viszonylag magas értékek mellett az állománynagyság is egyenletes képet mutatott és a populáció a vadászati hasznosításra sem volt érzékeny.

A mezei nyúl növényevő, így az év különböző időszakában jelentősen változnak a rendelkezésre álló táplálékforrások. Az egyszikü pázsitfüfélék mellett a kétszikü gyomok is helyet kapnak étrendjében, a természetes gyepek mellett az ugarok, a vetett gyepek és lucernaföldek is meghatározó élőhelynek számítanak. A legnagyobb egyedsürüséget a változatos szántóföldi kultúráknál találjuk, ahol a késő őszi, téli időszakban kulcsfontosságú lehet az egyes mezőgazdasági kultúrák szerepe (őszi káposztarepce, őszi búza). Ezt bizonyította a Túzokvédelmi Mintaterületen alkalmazott vetésforgó alkalmazása, itt mértük 2008 októberében a legnagyobb állománysürüséget, amely elérte a 3,76 db/ha értéket. A rendszeresen legeltetett gyepek esetében a kedvező szántóföldi kultúráknál alacsonyabb egyedsürüséggel találkozhatunk (SMITH et al., 2005; JENNINGS et al., 2006), amely mind a három mintaterület esetében érzékelhető volt.

A szántóföldi tábláknál a különböző művelési módok, technológiai elemek drasztikus változásokat eredményezhetnek, akár egyes kiemelt jelentőségü élőhelytípusok teljes egészében el is tünhetnek. A kaszálások, a gabonafélék learatása, majd a tarlók azonnali betárcsázása vagy az őszi mélyszántás órák alatt el tudja tüntetni a mezei nyulak mozgáskörzetéből az addig rendelkezésre álló táplálékforrásokat. Ennek következménye a rendszeresen előforduló, jelentős pusztulásokat eredményező táplálékhiány kialakulása (GÁL \& MAROSÁN, 2004), így a mezei nyúl által használt otthonterület akár termesztéstechnológiai ökológiai csapdává is válhat (FARAGÓ, 2012). A Réhely mintaterületen a szántóföldi használat esetében jól nyomon követhető a nagytáblás művelési rendszer élőhelyi hatása. Az őszi gabonafélék betakarítását követő tárcsázások és a területre jellemző 
napraforgótermesztés a mezei nyúl állománynagyságának szélsőséges hullámzását eredményezték, ahol a gyakori drasztikus csökkenés is megfigyelhető, melyre jó példa a 2009-es esztendö.

A vizsgálat során a legnagyobb állománysűrüségi mutatókat a Túzokvédelmi Mintaterületen rögzítettük. 2008 őszén a Túzokvédelmi belső mintaterületen nagyon magas, $3,76 \mathrm{db} /$ ha értéket regisztráltunk. Hasonlóan zárt és ,rókamentes” területen Dániában végeztek átfogó vizsgálatokat (ABILDGARD et al., 1972). A felmérések szerint az Illumo szigetén élő mezeinyúl-populáció állománysürüsége ( 2 egyed/ha) magasabb a dániai átlagnál. A Túzokvédelmi belső mintaterületen mi is magasabb értékeket becsültünk, mint a külső kontrollterületeken. A szigeten élő populációnál jól nyomon követhető volt egy állományösszeomlás. A dévaványai vizsgálatok során a 2010-es belvizes, esős és hüvös időjárási körülmények eredményeztek hasonló pusztulásokat. Nagyon érdekes tapasztalat, hogy a szigeten élő emberek találtak ugyan elpusztult nyulakat, de az egyedek többsége nyom nélkül eltünt. A Túzokvédelmi Mintaterület kezelő személyzete szintén nem érzékelte az egyébként jól kimutatható tömeges pusztulásokat.

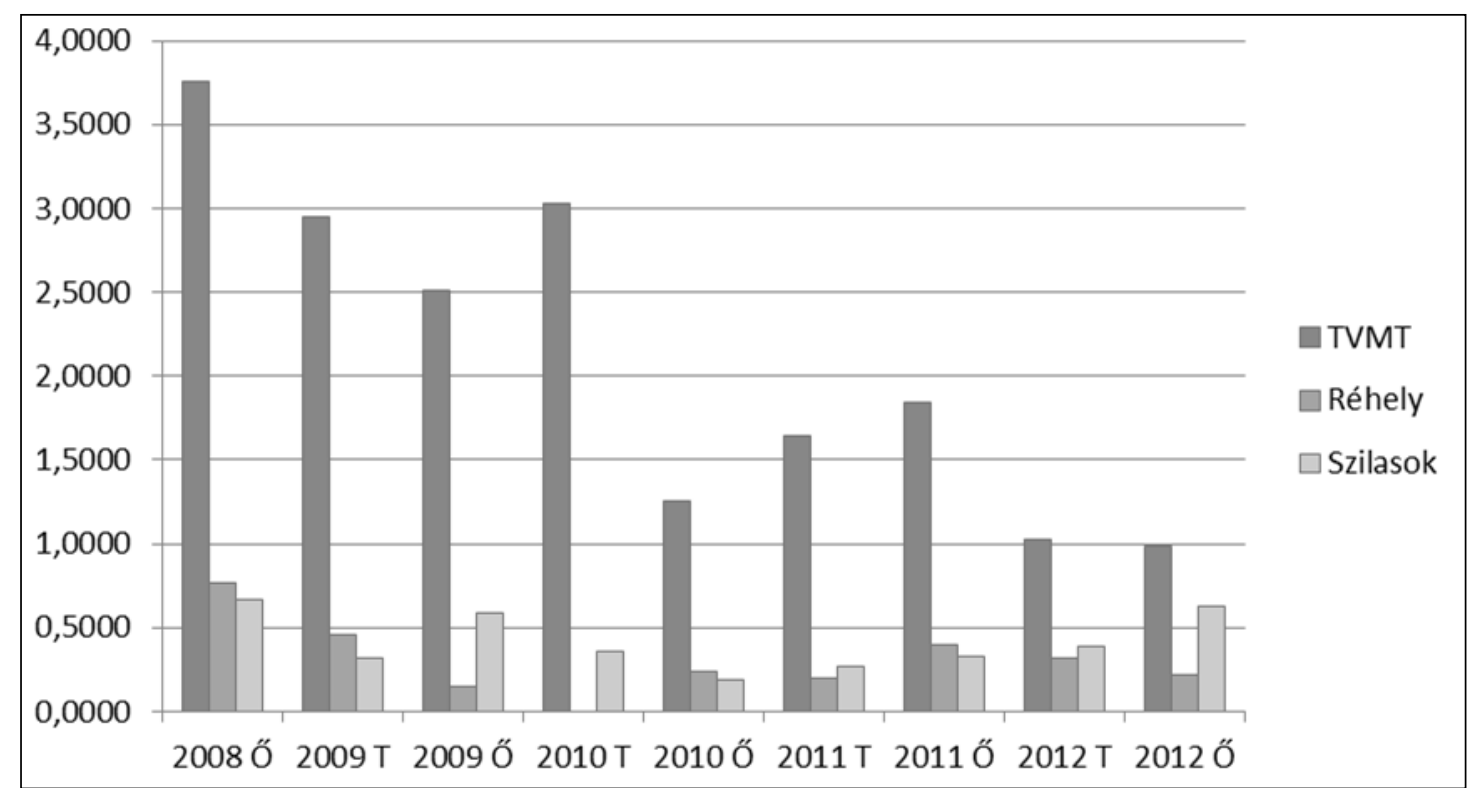

21. ábra: A mezei nyúl állománysűrüségének (db/ha) változása a mintaterületeken Figure 21: Changes in Brown Hare population density on the sample sites

\section{Az időjárás hatása a vizsgálati időszakban}

A mezei nyúl hazai elterjedését az éghajlati tényezők és az élőhelyi sajátosságok határozzák meg (KOVÁCS, 2007). Az állománysürüség csökken a tengerszint feletti magasság, az éves átlagcsapadék és az évente hóval fedett napok számának növekedésével, illetve az éves napsütéses órák számának és az évi középhömérséklet csökkenésével (PIKULA et al., 2004). Szélsőséges időjárási helyzetek, például a rendkívüli szárazság vagy a hosszú fagyoshavas téli időszak tömeges elhullást okozhat a mezei nyulak esetében. A hüvös, csapadékos időjárás jelentős pusztulást okozhat a kis nyulak körében is (SMITH et al., 2005).

Az elvégzett vizsgálatok szerint 2008 és 2012 között három rendkívüli időszak különíthető el, ami kritikus időjárási helyzetnek tekinthető (21. ábra). 
2010 tavaszi csapadékos időszak hatása

A 2009-2010-es téli csapadék rendkívüli belvízi helyzetet teremtett, melyet egy hủvös, csapadékos „Medárd-napi” ciklus követett. A Réhely mintaterületen a 2010 tavaszi számlálást a rendkívüli útviszonyok miatt nem lehetett megvalósítani, így csak a Szilasok mintaterület és a Túzokvédelmi belső mintaterület adatait tudtam összehasonlítani. A mezei nyúl felmérések 2010 tavasztól-őszig terjedő időszakra, a szaporodási ciklus ellenére, állománycsökkenést mutatnak, ahol a csökkenés mind a Szilasok $(t=4,906 ; \mathrm{p}<0,05)$, mind a Túzokvédelmi belső mintaterület $(t=4,571 ; \mathrm{p}<0,05)$ esetében szignifikáns volt.

\section{2. februári havas időszak hatása}

A 2012. február 2-i hóesést követő 4 hetes fagyos hóborítás eltérő hatást váltott ki a három mintaterület esetében:

Réhelyi és a Szilasok mintaterület: állományváltozást nem eredményezett $(t=1,002$; $t=0,828 ; \mathrm{p}<0,05)$ a mezei nyulak a szabad mozgásuknak köszönhetően fel tudták kutatni a szükséges táplálékforrásokat, így a havas, fagyos szélsőséges körülményekkel jellemezhető időszakot sikeresen átvészelték.

Túzokvédelmi belső mintaterület: a mezeinyúl-állomány szignifikánsan $(t=10,775$; $\mathrm{p}<0,05$ ), közel 45\%-kal csökkent az öszi felmérésekhez képest, a szegélyhatás nem érződik. A nyulak a kerítés miatt csak a zárt területen tudtak mozogni, ahol nem találtak a kritikus időszakban megfelelő táplálékforrást.

\section{2 évi nyár végi szárazság hatása}

A 2012 évi nyár vége, ősz eleje rendkívül száraz volt, amit mérsékelt egy rövid, az őszi káposztarepce kelését segítő csapadékos ciklus. A tavaszi és az őszi adatokat összehasonlítva megállapítható, hogy a Szilasokon $(t=4,841 ; \mathrm{p}<0,05)$ szignifikáns állománynövekedést tapasztaltunk, míg a Réhelyi mintaterületen $(t=2,257 ; \mathrm{p}<0,05)$ és a Túzokvédelmi belső mintaterületen $(t=0,485 ; \mathrm{p}<0,05)$ eltérés nem volt kimutatható. A két utóbbi mintaterületen egyrészt a zártság, másrészt az intenzív szántók magas aránya eredményezte a szükséges táplálékforrások hiányát.

\section{A vadászati hasznositás hatása}

A Szilasok mintaterület adatait megvizsgálva jól látható a 2010-es mélypont $(0,18 \mathrm{db} / \mathrm{ha})$, melyet a mezeinyúl-állomány fokozatosan kihevert és 2012 öszére újra elérte (0,63 db/ha) a 2008 és 2009 őszére jellemző állománysürüségi értéket. A fenti adatok azt bizonyítják, hogy a szakszerü vadászati hasznosítás érdemben nem befolyásolta a törzsállományt, ha a populáció számára a kedvező élőhelyi feltételek végig adottak.

Ha összehasonlítjuk a rendszeres vadászati hasznosítással érintett, kiváló élőhelyi adottsággal rendelkező Szilasokat és a mezei nyúl vadászati hasznosításával nem érintett, nagytáblás mủvelési rendszerrel jellemezhető Réhelyt, az alábbiakat tapasztalhatjuk. A két mintaterület állománysürüségi adatait 8 felmérési időpontban tudjuk összehasonlítani (a belvíz miatt 2010 tavasza kiesik). A vizsgálatot $\mathrm{p}<0,05$ szignifikancia szinten végeztem el. Többségében, 5 esetben (2008 ösz - $t=0,905 ; 2010$ ösz - $t=1,384 ; 2011$ tavasz $-t=1,108$; 2011 ösz - $t=0,677 ; 2012$ tavasz $-t=1,947)$ nem mutatható ki eltérés, 2 esetben a Szilasokon 
(2009 ösz - $t=11,787 ; 2012$ ösz - $t=10,881$ ), míg 1 esetben Réhelyen (2009 tavasz $-t=3,126)$ magasabb szignifikánsan az állománysürüség. Itt kell meg jegyezni, hogy ezekben az esetekben jelentős szerepet játszanak a nagytáblás, drasztikus élőhelyváltozások Réhelyen. 2009 és 2012 öszén amikor a Szilasokon magasabb volt az állománysürüség, alig és foltosan kelt ki az őszi búza. Ezekben az években az őszi szántó Réhelyben 59,05\%-ot és 68,86\%-ot, míg a Szilasokon 41,51\%-ot és 30,26\%-ot tett ki.

Összefoglalva megállapítható, hogy a mezei nyúl szakmai elöírásokat szemelőtt tartó, szakszerü vadászati hasznosítása a mezeinyúl-állomány nagyságát nem befolyásolja.

\section{A vörös róka jelenlétének hatása}

Ha a vörös róka előfordulása alapján hasonlítjuk össze a „rókamentes” Túzokvédelmi Mintaterület és az állandó rókaállománnyal rendelkező Réhelyt és Szilasokat, akkor a következő eredményeket kapjuk. A Túzokvédelmi belső mintaterület mezeinyúlállománysürüsége a Szilasokéval $\mathrm{p}<0,05$ szignifikancia szinten összevetve minden esetben szignifikánsan magasabb. A Túzokvédelmi belső mintaterület és Réhely összehasonlításakor szintén minden esetben a belső mintaterület állománysürüsége szignifikánsan magasabb.

A kapott eredmények azt mutatják, hogy a vörös róka predációs hatása a mezei nyúl esetében kiemelkedő jelentőségü.

\section{A szegélyhatás jelensége}

A Szilasokon 2010-2011, 2011-2012 között, a Túzokvédelmi belső mintaterületen 2009-2010, 2010-2011 között őszről tavaszra nőtt a felmért egyedszám. Ez a jelenség a fenti két mintaterület esetében a tavaszi szegélykoncentrálódást mutatja. A Réhely mintaterület esetében minden őszi becslést csökkenő tavaszi egyedszám követ, itt nincs koncentrálódásra utaló érték.

\section{A Túzokvédelmi belső mintaterület mezeinyúl-állományának csökkenö jelensége}

A Túzokvédelmi belső mintaterületen élő mezeinyúl-populáció állományváltozását nyomon követve, 2008 ősze és 2012 ősze között több lépcsőben lezajló, jelentős csökkenést tapasztalhatunk. Először az esős-belvizes időszaknak köszönhetően, 2009 ősze és 2010 ősze között csökkent szignifikánsan $(t=12,814 ; \mathrm{p}<0,05)$ az állománysürüség, mintegy $50 \%$-os állománycsökkenést szenvedve el. Ezt követően 2010 ősze és 2011 ősze között állománynövekedésnek lehetünk tanúi, ahol a kedvező tendenciát a 2012. februári havasfagyos időszak töri meg. A 2012 nyár végi, ősz eleji szárazság kedvezőtlen hatásának köszönhetően, további enyhe csökkenést mutatnak a felmérések, azonban az eltérés nem volt szignifikáns $(t=0,485 ; \mathrm{p}<0,05)$. Az állománysürüség ekkor éri el a becsült legalacsonyabb 0,99 db/ha-os értéket. A 2011 öszi és a 2012 őszi adatok összevetése már szignifikáns csökkenést $(t=19,721 ; \mathrm{p}<0,05)$ mutat.

\section{A zárt és a nyitott terület mezeinyúl-állományának összehasonlítása}

Érdemes összehasonlítani a vizsgálati időszakban a Szilasok és a Túzokvédelmi belső mintaterület állományváltozását. 2008 őszén a Túzokvédelmi belső mintaterület állománysürüsége még 5,60-szorosa volt a Szilasokénak, míg a több lépcsőben lezajlott folyamatos csökkenésnek köszönhetően, 2012 öszére a Túzokvédelmi belső mintaterület állománysürüsége már csak 1,56-szor volt magasabb a Szilasokénál. A két mintaterület 
becsült adatai 2008 ősze és 2012 ősze között, mind a 8 esetben szignifikánsan $(\mathrm{P}=0,05$ szignifikancia szint) eltértek (22. ábra). A vizsgálatok azt bizonyítják, hogy a mezeinyúlpopuláció a zárt területnek köszönhetően sem a szélsőségesen száraz, sem a tartós faggyal kísért hótakaró esetében, a szabad mozgás korlátozása miatt, nem tudott tartalék táplálkozó helyeket felkeresni, amivel át tudta volna vészelni a rendkívül megterhelő időszakot, szemben a szabad területen élő Szilasok mezeinyúl-állományával.

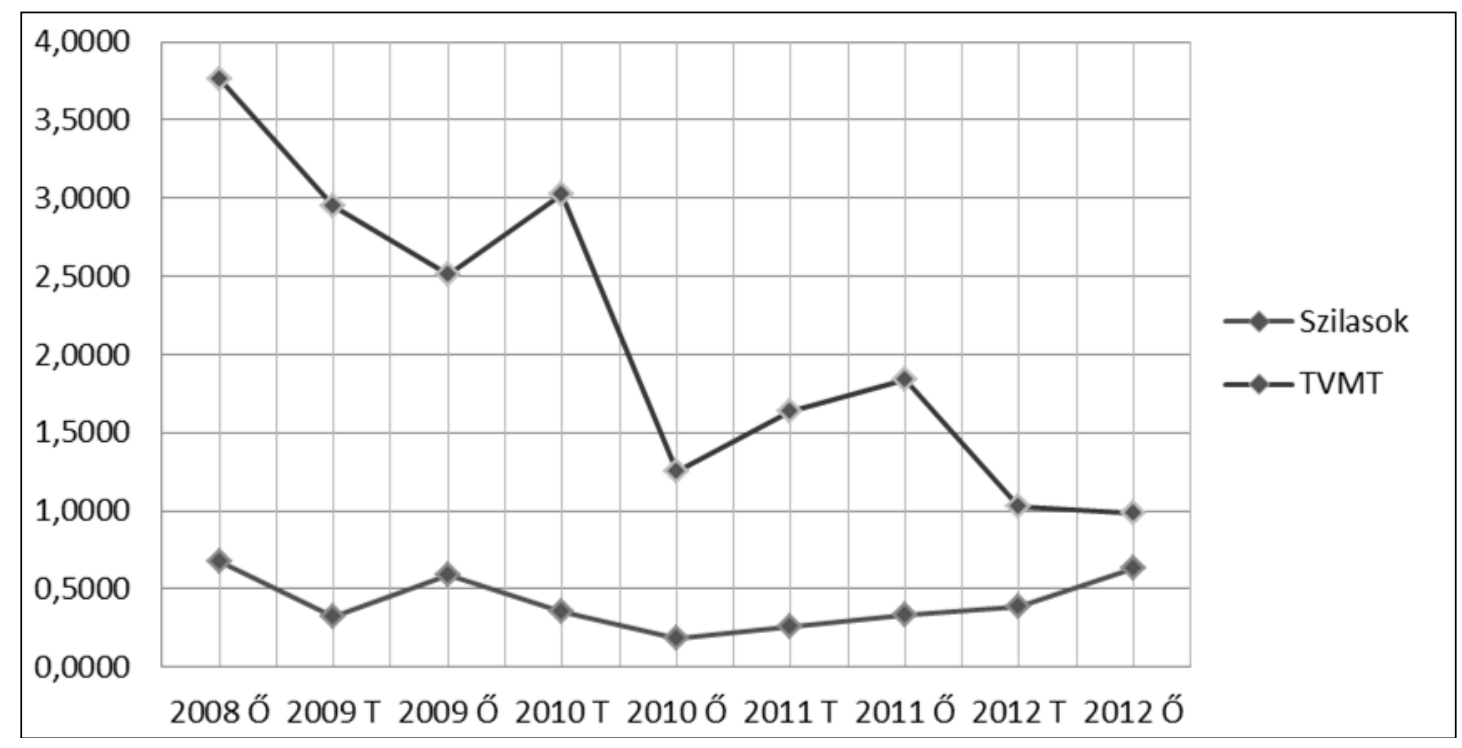

22. ábra: A mezei nyúl állománysürüségének (db/ha) változása a Túzokvédelmi belső mintaterületen és a Szilasok mintaterületen

Figure 22: Changes in Brown Hare population density on the Great Bustard Interior and the Szilasok Sample Site

\section{ÖSSZEFOGLALÁS}

A Körös-Maros Nemzeti Park Igazgatóság 2003-ban helyezte üzembe a dévaványai Túzokvédelmi Mintaterületet. A kialakítás elsődleges céljaként egyes speciális túzokvédelmi feladatok ellátását, mint például a különböző típusú repatriációs módszerek kipróbálását, megvalósítását, illetve egy területkezelési modell kidolgozását jelölték meg a szakemberek. A Túzokvédelmi Mintaterület egy speciális kerítéssel lezárt 398 hektáros terület, ahonnan a földön fészkelő madarakra jelentős hatással bíró, közepes méretü vagy annál nagyobb ragadozó, illetve vegyes táplálkozású emlősök kizárásra kerültek. Ebbe a körbe tartozik a környéken elöforduló vörös róka (Vulpes vulpes), a növekvő állományú aranysakál (Canis aureus), a kóbor kutya (C. familiaris), az európai borz (Meles meles), a nyestkutya (Nyctereutes procyonoides) és a mára állandó vadfajjá váló vaddisznó (Sus scrofa).

A rendkívül száraz 2002-es esztendöben történt a müszaki kivitelezés, a terület végleges lezárása, ahol nemcsak a fészkelő madarakra veszélyt jelentő emlősfajok egyedeinek eltávolítását kellett megoldani ( 8 vörös róka, 1 európai borz), de a benn maradt vadászható emlősfajok (őz, mezei nyúl) állományszintjének beállításáról is gondoskodni kellett.

A mezei nyúl (Lepus europaeus) állományának összehasonlító vizsgálatára kiterjedő kutatási program 2008 és 2012 között 9 felmérési időszakot foglalt magába. A kutatás során 3 mintaterület került kijelölésre, melyek abban különböztek egymástól, hogy volt-e vörös róka a területen és történt-e mezei nyúl vadászati hasznosítás. A mintaterületeken évente kétszer 
(összel, tavasszal) éjszakai reflektoros felmérési módszerrel végeztük el az állománybecsléseket. A legnagyobb állománysürüséget 2008 októberében becsültük a Túzokvédelmi belső mintaterületen, ahol a becslés $3,76 \mathrm{db} /$ ha sürüséget mutatott. A vizsgált időszakban három esetben alakult ki olyan időjárási helyzet (rendkívüli csapadék, hosszú havas időszak, szélsőséges szárazság), amely a mezeinyúl-állományt súlyosan érintette. Az izolált körülmények között, illetve a szabadterületen élő mezeinyúl-állományoknál a szélsőséges időjárás eltérő következményekkel járt, a zárt populáció jóval érzékenyebben reagált. A vizsgálati időszak eredményei azt bizonyították, hogy a szakszerü vadgazdálkodási tevékenység a mezeinyúl-állomány nagyságát nem befolyásolta a kijelölt mintaterületeken. A vörös róka predációs hatása a külső mintaterületeken egyértelmüen kimutatható volt és kiemelkedő jelentőséggel bírt.

\section{KÖSZÖNETNYILVÁNÍTÁS}

Ezúton köszönöm meg LENGYEL TiBORnak, PARCZEN BALÁZSnak és SzÉLl ANTALnak az éveken át tartó éjszakai reflektoros becslésben, illetve a kutatásban való kitartó részvételüket, DR. FARAGÓ SÁNDORnak, KALIVODA BÉLÁnak és BÁNFI PÉTERnek a szakmai iránymutatást, CZIFRÁK GÁBORnak a technikai támogatást, FAZEKAS EDITnek az elengedhetetlen informatikai segítséget és SCHMIDT ANDRÁSnak a nyelvi támogatást.

\section{IRODALOMJEGYZÉK}

Abildgard, F., Andersen, J. \& Barndorff-Nielsen, O. (1972): The Hare Population (Lepus europaeus PALlaS) of Illmö Island, Denmark. A Report on the Analysis of the Data from 19571970. Danish Review of Game Biology Vol. 6. No.5.

BíRÓ Zs. (1996): Adatok a mezeinyúl esti aktivitásának szabályozásáról. Vadbiológia 5: 133-140.

BíRÓ ZS. \& SZEMETHY L. (2002): A Kovács-Heltay féle mezeinyúl gazdálkodási modell kritikája és továbbfejlesztésének lehetősége. Vadbiológia 9: 73-82.

DEMETER A. \& KOVÁCS GY. (1991): Állatpopulációk nagyságának és sürüségének becslése. Akadémiai Kiadó, Budapest.

DÖVÉNYI Z. (szerk.) (2010): Magyarország kistájainak katasztere. MTA Földrajztudományi Kutatóintézet, Budapest, p. 249-252.

FARAGÓ S. (2012): A vetésszerkezet és az élőhely diverzitás-változása. In Faragó S. (szerk.): A LAJTA Project - Egy tartamos mezei vad és ökoszisztéma vizsgálat 20 éve. - Nyugatmagyarországi Egyetem Kiadó, Sopron. pp. 118-133.

FARAGÓ S. \& NÁHLIK A. (1997): A vadállomány szabályozása. A fenntartható vadgazdálkodás populációökológiai alapjai. Mezőgazda Kiadó, Budapest.

FRYLESTAM, B. (1981): Estimating by Spotlight the Population Density of the European Hare. Acta Theriologica 26: 419-427.

GÁL J. \& MARosán M. (2004): A mezei nyúl (Lepus europaeus) élőhelyhasználata. A Vadgazda 3(3): 24.

IVLEV, V. S. (1961): Experimental ecology of the feeding of fishes. Yale University Press, New Haven, Connecticut

JACOBS, J. (1974): Quantitative Measurement of Food Selection. A Modification of the Forage Ratio and Ivlev's Electivity Index. Oecologia 14: 413-417. http://dx.doi.org/10.1007/BF00384581

JenNings, N., SMith, R. K., HACKLÄNDER, K., HARRIS, S. \& White, P. C. L. (2006): Variation in demography, condition and dietary quality of hares Lepus europaeus from high-density and low-density populations. Wildlife Biology 12: 179-189. http://dx.doi.org/10.2981/09096396(2006)12[179:VIDCAD]2.0.CO;2 
KovÁCs Gy. (1986a): A szaporodási ciklus befejező szakasza a mezeinyúlnál: Mikor kezdődjön a vadászati idény? Vadbiológia 1: 23-29.

KovÁCS GY. (1986b): Létszámbecslési módszer gyakorló vadgazdáknak: a mezeinyúl állománysürüségének becslése reflektorral. Vadbiológia 1: 73-79.

KovÁcs Gy. (2007): Mezei nyúl. In Bihari Z., CsORBA G. \& Heltai M. (szerk.): Magyarország emlöseinek atlasza. Kossuth Kiadó, Budapest, pp. 130-130.

PIElowsKi, Z. (1969): Belt Assessment as a Reliable Method of Determining the Numbers of Hares. Acta Theriologica 14(9): 133-140.

Pikula, J., Beklova, M., Holesovska, Z. \& Treml, F. (2004). Ecology of European brown hare and distribution of natural foci of tularaemia in the Czech Republic. Acta Veterinaria Brno 73(2): 267-273. http://doi.org/10.2754/avb200473020267

SMITH, R. K., JENNINGS, N. \& HARRIS, S. (2005): A quantitative analysis of the abundance and demography of European hares Lepus europaeus in relation to habitat type, intensity of agriculture and climate. Mammal Review 35(1): 1-24. https://doi.org/10.1111/J.13652907.2005.00057.X

SVÁB J. (1973): Biometriai módszerek a kutatásban. Mezőgazdasági Kiadó, Budapest.

VALLER A. (2010): Békés Megyei Szakigazgatási Hivatal Földmüvelésügyi Igazgatóság 13.04/1263/2010. számú Körlevele. Békéscsaba, 2010. 